Eric Borgström

Doktorand i svenska språket

Institutionen för humaniora, utbildnings- och samhällsvetenskap

Örebro universitet

\title{
Vad räknas som belägg för skrivförmåga? \\ Ett textkulturellt perspektiv på skrivuppgifter i den svenska gymnasieskolans nationella prov
}

\begin{abstract}
This article examines writing tasks in Swedish national tests from 2007-2012. My aim is to examine some ways in which writing ability are conveyed by the test. For this purpose I combine concepts such as construct and target domain from test theory, with a text theoretical/sociocultural approach to writing. Within this framework I examine which written mediations count as evidence of writing proficiency (i.e. that are given text value) in the test context. The writing tasks are analyzed through the dimensions of themes, text structures, and acts of writing. I also analyze the writer roles implied by these tasks. The analysis shows that the test construction brings four distinct and recurrent task types to the fore. Based on those results I reconstruct the target domains of the tests, and discuss the prerequisites of their validity, from the perspective of writing theories on the one hand, and of the established course objectives on the other.

Det är välbekant att utformandet av prov i skrivande innebär många och komplexa utmaningar. Prov har att vara verksamma i specifika sociohistoriska och institutionella sammanhang och syftena de konstrueras utifrån varierar. Varje konstruktion vilar på antaganden om hur de gällande syftena bäst uppnås i sammanhanget, på empiriska analyser och på värderingar. Vilka slags yttranden som räknas som belägg för skrivförmåga, och vad som tjänar som referenspunkter vid bedömning av dem varierar, liksom innebörden i begreppet skrivförmåga.

I den här studien riktas intresset mot svenskämnets nationella skrivprov. Syftet är att rekonstruera några drag i provkonstruktionens konkretisering av begreppet skrivförmåga. Detta gör jag genom att kombinera testteori och textteori. De testteoretiska begreppen använder jag dels för att sätta in provkonstruktionen i sitt psykometriska sammanhang, dels för att sätta ramarna och giltighetsanspråken för studien. Textteorin preciserar perspektivet på skrivande. I centrum för undersökningen står de texter i provkonstruktionen som tjänar för att omsätta skrivideologi till empiri i bedömningsproceduren, nämligen skrivuppgifterna.
\end{abstract}


Den nordiska språkvetenskapliga forskning som berör externa skrivprov har vidgats i angreppssätt och forskningsintressen. Traditionen efter Hultman \& Westmans Gymnasistsvenska (1977) att leta kvantitativa och kvalitativa språkliga och textuella korrelat till betygsnivåer i elevtexter har följts upp av exempelvis Larsson (1984) och Östlund-Stjärnegårdh (2002) och är alltjämt relevant, med Skjelten (2013) som senaste tillskott. Samtidigt har andra aspekter av - och aktörer $\mathrm{i}$ - bedömningsproceduren kommit att införlivas och bidra till att fördjupa våra kunskaper om skrivprov som fenomen. Så fångas bland annat exempelvis elevers erfarenheter av mötet med prov hos Nyström (2000) och Parmenius-Swärd (u.u.), och norsksensorers skrivsyn och hur den inverkar på elevers resultat tas upp av Berge (1996). Skrivuppgifter som genre och ideologisk produkt belyses av Ongstad (1996), och deras inverkan på elevtexters struktur behandlas i Borgström (2010). Vidare har provkonstruktioner i bredare bemärkelse studerats och varit föremål för såväl skriv- som mätteoretiskt grundad diskussion, i Norge genom KAL-prosjektet (Berge $\mathrm{m}$ fl 2005a, 2005b), och i Danmark genom Smedegaard (2013).

För den svenska gymnasieskolans prov saknas ett större grepp om den konkretisering av begreppet skrivförmåga som proven ger uttryck för (jfr Borgström 2012). Till detta vill den här studien utgöra ett, av förhoppningsvis flera, bidrag. Föremål för studien är den provkonstruktion som var i bruk för kursen Svenska B i den förra läroplanen, Läroplanen för de frivilliga skolformerna (Lpf94). Dessa prov har sedan 2011 års läroplansskifte successivt ersatts av prov framtagna utifrån den nya ämnesplanen. De nya proven skyddas emellertid under implementeringen av en extra lång sekretesstid, och omfattas inte i den här studien.

Artikeln är upplagd så att jag först för den nordiska läsaren kort presenterar det svenska provsystemets syften och några tongivande användningar. Därefter ramar jag in undersökningens intresse och dettas relation till det huvudsakliga imperativet för skrivprov, nämligen validitet. I avsnittet efter det presenterar jag det textteoretiska perspektiv på skrivande och text som jag anlägger. Så presenterar jag provkonstruktionens upplägg och anspråk i stora drag, sedan materialet jag undersöker och mina specifika analytiska ingångar. Därefter redogör jag för resultaten, och avslutar med ett diskussionsavsnitt.

\section{Provsystemets syften och användningar}

Den svenska gymnasieskolans nationella provsystem togs i bruk mot slutet av 1990-talet, strax efter att Lpf94 och det tillhörande målrelaterade betygssystemet, introducerats. Tillsammans med prov i engelska och matematik utgjorde svenskämnesproven ett nationellt provsystem vars syfte var - och alltjämt är - att fungera såväl främjande som granskande. Det ska dels stödja likvärdighet och rättvisa $\mathrm{i}$ bedömning och betygssättning i den i decentraliserade svenska skolan, och dels ge underlag för analys av måluppfyllelse på aggregerad nivå (www.skolverket.se). Andra syften med provsystemet, som dock tonats ner något i senare års policytexter, är att de kan 
bidra till att konkretisera kursplaner för lärare och elever, och till ökad måluppfyllelse för eleverna (för en detaljerad historik se Lundahl 2010).

I den svenska gymnasieskolan sätter läraren själv kursbetyg på sina elever och har därmed en dubbel roll, som både handledare och ansvarig för den slutliga bedömningen. Det gäller även för de nationella proven. För delprov med öppna svarsformat, som skrivproven, rekommenderar Skolverket kollegial sambedömning. Provbetygen sätts med samma skala som slutbetygen vilket under Lpf94 innebar stegen Icke godkänd, Godkänd, Väl Godkänd och Mycket Väl Godkänd (hädanefter IG, G, VG och MVG). I proven kunde dock läraren gradera steg med + respektive för särskilt starka respektive svaga prestationer inom ett betygssteg, utom i skalans ytterligheter IG och MVG.

Provens uppgift är att stödja lärarens betygssättning och de är således inga examensprov. Hur stor vikt ett provresultat på individnivå ska ges vid betygssättning är upp till läraren att avgöra. Proven utgör med andra ord en möjlighet för läraren att få en second opinion om elevers prestationsnivåer, och för eleven en ytterligare chans att visa vad man kan. På aggregerad nivå är provresultatens styrning starkare, och den skola som uppvisar systematiska avvikelser mellan provbetyg och kursbetyg ska kunna förklara detta. Såväl provresultat som slutbetyg publiceras på Skolverkets webbsida SIRIS (http://siris.skolverket.se), där var och en kan plocka fram statistik på skol-, huvudmanna- och nationell nivå.

Provresultaten utgör också information till allmänheten inför skolval. Det svenska skolsystemet är avreglerat, och kommunala och fristående skolor konkurrerar med varandra om eleverna och de ekonomiska medel som följer dessa. Resultat är det viktigaste konkurrensmedlet. Så har betygsinflation varit ett begrepp i den svenska skoldebatten. Systemet att lärare både rättar proven och sätter betyg bidrog till att misstankar om systematisk otillbörlig påverkan av provresultat väcktes, så kallad haloeffekt. Detta föranledde att Skolinspektionen uppdrogs att under tre år utföra så kallade "kontrollrättningar", vilka fătt stor medial uppmärksamhet. Skrivproven i svenska och engelska uppvisade vad inspektionen betraktade som en så kraftig avvikelse mellan ursprungsbedömning och kontrollrättning att man rekommenderade att dessa delar ströks ur provsystemet. Alternativt rekommenderades att proven kraftigt gjordes om. Skolinspektionens metodologi har dock kritiserats (Gustafsson \& Erickson 2013), och man har inte fått politiskt gehör för sina rekommendationer, även om kontrollrättningarna har permanentats.

\section{Skrivprov som pedagogisk mätning}

Pedagogisk mätning handlar om att under strukturerade former få fram bevis för att kunna dra slutsatser om något vi inte kan observera direkt, för att på så vis - i den bästa av världar - fatta beslut som är något mer transparenta och rättvisa jämfört med om man hade låtit bli. 
Detta osynliga något är det som på mätspråk för konstrukt. I färdighetstester, som skrivprov, är konstruktet intimt sammanflätat med det som kallas måldomän, nämligen de sammanhang utanför provet där konstruktet är i bruk. Det man vill dra slutsatser om är elevers prestationsnivå i måldomänen (jfr Kane m fl 1999), och det är konstruktet som ska förklara den spridning som uppstår i elevernas resultat. I Figur 1 nedan visualiserar jag den syn på proven och mätproceduren som jag anlägger. Modellen är en bearbetning av Kane (2006:33) ${ }^{1}$, och visar när den läses som ett U principiellt hur mätproceduren går från teoretiska antaganden om konstrukt och måldomän, via provuppgifter (testdomän) till tolkning av empiri.

\section{Mätprocedur}

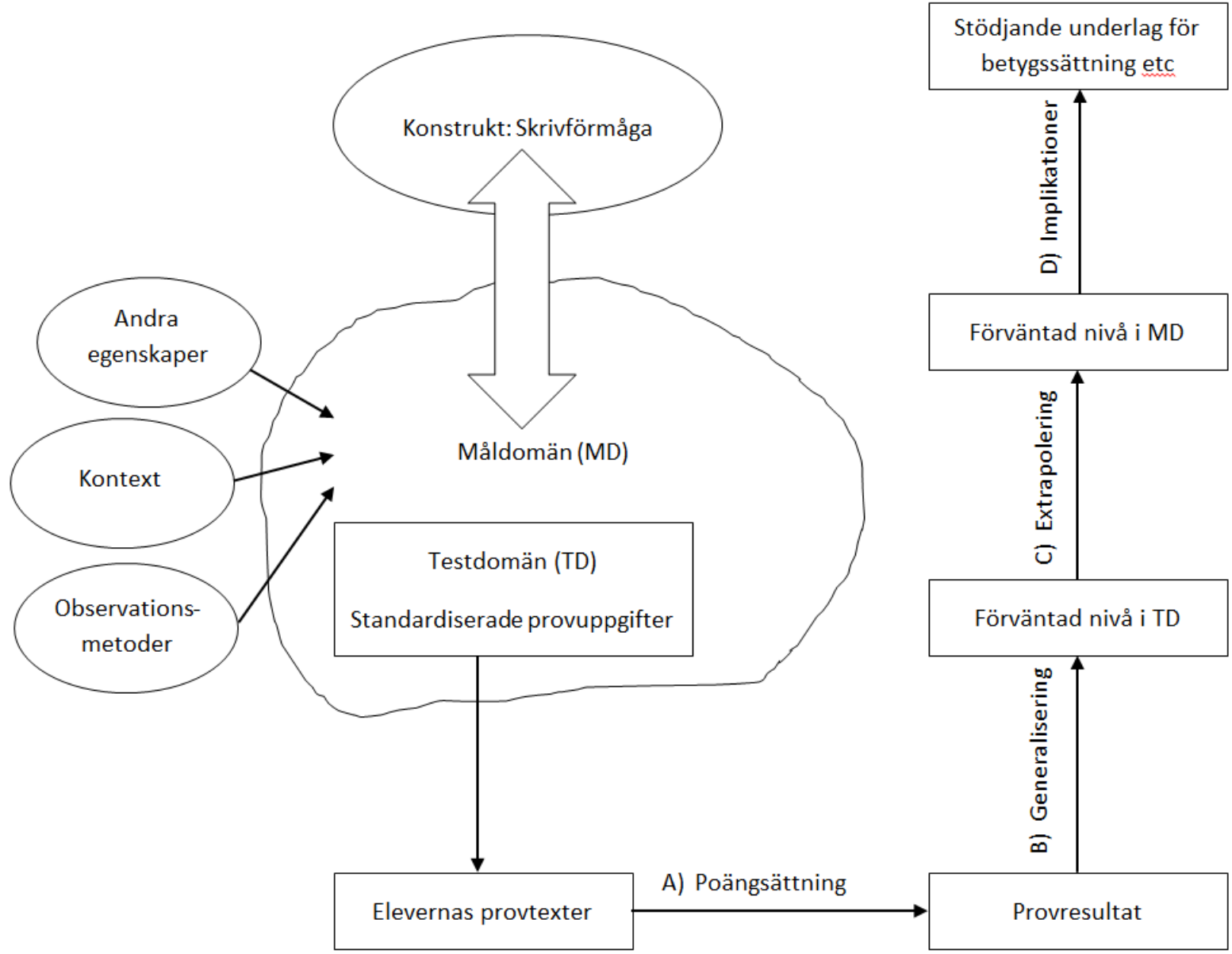

Figur 1. Mätproceduren och några centrala inferenser och implikationer, efter Kane (2006).

\footnotetext{
${ }^{1}$ I ursprungsversionen visualiserar modellen en mätning av ett psykologiskt karaktärsdrag (trait) som konstrukt. Här har jag anpassat den efter det jobb svenskämnesproven ska göra.

E. Borgström 
Jag riktar i den här undersökningen en kvalitativ analys mot det som i modellen kallas testdomän, vilket är det univers av skrivuppgifter proven ålägger elever i den kontextuellt standardiserade (reglering av tid, plats, redskap etc) provsituationen. I Bachman \& Palmers (2010) handbok för konstruktion av språkprov är begreppet konstrukt intimt förknippat med specifika skrivuppgifter. Konstruktet är "the specific definition of an ability that provides the basis for a given assessment or assessment task, and for interpreting scores derived from this task" (Bachman \& Palmer 2010:43). Definitionen av konstruktet är med andra ord både viktigt för framtagande av skrivuppgifter och för tolkning av resultat. I vissa fall, som där man ska använda testresultaten för att uttala sig om generisk skrivförmåga, bör konstruktsdefinitionen bygga på explicitgjorda skrivteorier. I fallet nationella prov ska resultaten istället peka på måluppfyllelse och definitionen baseras på det skrivkonstrukt som uttrycks i kursplanen. Kursplanens definition baseras i sin tur, åtminstone implicit, på skrivteorier och -ideologier (jfr Bachman \& Palmer 2010:213).

Det traditionella sättet att definiera konstruktet i skrivtester är att lista en uppsättning textuella, språkliga och motoriska delkompetenser som krävs för att lösa uppgiften och utgör det man vill dra slutsatser om (jfr Purves m.fl. 1988 för konstruktsdefinitionen i det enda ambitiösa försöket till internationell mätning av skrivförmåga, den så kallade IEA-undersökningen). Prov och uppgifter måste vara så breda att de verkligen ger möjlighet att fånga det man vill ska fångas, men inte så breda att de famnar över annat än konstruktet. Båda dessa utgör potentiella hot mot validiteten (jfr Messick 1989:34). Ett vanligt dilemma för den som vill mäta skrivförmåga är om innehållskunskaper ska ingå i konstruktet eller inte. Det ställningstagandet guidar nästa utmaning, nämligen vad skrivuppgifterna och därmed elevernas texter ska handla om.

Förutom konstruktet är alltså måldomänen central vid framtagande av provuppgifter. Bach-man \& Palmer (2010:60) definierar för språktester måldomänen som "a specific setting outside the test itself that requires the test taker to perform language use tasks". Ett test kan bygga på en eller flera måldomäner. Med utgångspunkt i de användningsområden provresultaten ska ha, har provkonstruktörer att sortera ut vilken eller vilka kommunikationssfärer utanför provet självt som utgör testets måldomäner. Vidare har man att specificera vilka uppgiftstyper måldomäns-uppgifter - som finns därinom, och som är relevanta att testa givet provets användning. Det hand-lar om vilka syften eleverna ska skriva i, vilka mottagare man ska rikta sig till etc (jfr Vähäpassi 1988 om domänteorin bakom IEA-undersökningen). Specifikationen av måldomänsuppgifter kan sedan ligga till grund för uppgifter som simulerar måldomänsuppgifter i den standardiserade test-domänen.

Som Figur 1 visar hänger konstrukt och måldomän nära ihop. Ur sociokulturellt orienterade perspektiv på begreppet skrivande, där skrivande handlar om att delta i kulturella praktiker ge-nom att på relevanta vis mediera sociala handlingar, kan man säga att vissa aspekter av mål-domänen är inneboende i konstruktet. Detta betonas i det norska skrivkonstruktet Skrivehjulet där skrivande som grundläggande färdighet på en idealtypisk nivå definieras som förmågan att mediera sex olika grundläggande skrivhandlingar i sex olika skrivsyften, vilka 
konkretiseras i relation till läroplanens kunskaper och innehåll. Den handling som ska medieras har konse-kvenser för flera av de textuella och språkliga dimensioner som bedöms, exempelvis struktur och stil, och som traditionellt tillförs konstruktet (Skrivehjulet presenteras på s. 14).

Prov handlar om att dra slutsatser om prestationsnivåer, i fallet med nationella prov för att använda dessa slutsatser som underlag till betygssättningen. Validering handlar om att undersöka och värdera den empiriska och teoretiska hållbarheten i slutsatser och handlingar baserade på testresultat. Validitetsstudier i teknisk mening riktar sig därför inte mot provverktyget isolerat, utan mot något av inferensstegen i kedjan A-C (A Poängsättning osv.) i Figur 1. Varje steg förstås enligt gängse mätteori som ett Toulminskt strukturerat tolkningsargument (jfr Kane 2006) där provbrukaren går från data till påstående, baserat på antaganden och olika slags empiriska och teoretiska stöd. Inferenssteg A i modellen är föremål för studier av det som på mätspråk kallas interbedömarreliabilitet, det vill säga hur överens bedömargruppen är om vad som kännetecknar prestationsnivåer. Inferenssteg B är föremål för det som kallas generaliserbarhetsstudier. Det handlar enkelt uttryckt om i vilken utsträckning resultat kan antas vara stabila från en provuppsättning till en annan. Extrapoleringsinferensen $(C)$ handlar i sin tur om att gå från den nivå eleverna förväntas vara förmögna att prestera inom provet till att dra slutsatser om prestationsnivån utanför den aktuella provkonstruktionen, det vill säga i det som provet definierar som måldomän. Påståendet "ställd inför uppgift A $i$ situation $B$ i verkliga livet är det rimligt att eleven är förmögen att prestera text av nivå- $Z$ ' är ett exempel på en extrapolering. Detta bygger på närhet mellan det skrivande som sker i testdomänen, och det skrivande i måldomänen man vill uttala sig om. Kontextuellt fylliga provuppgifter som autentiskt simulerar måldomänen tar tid att genomföra. I praktiken måste varje provkonstruktion därför välja mellan att prioritera extrapoleringsledet eller generaliserbarhetsledet. Låg brukarlegitimitet, det som kallas face validity, kan vara ett tecken på brister i extrapoleringsledet.

Det jag gör i den här undersökningen är att ur ett textteoretiskt perspektiv och på aggregerad nivå belysa extrapoleringsledet - det vill säga vilka idealtypiska former av skrivande proven ger uttryck för att ha bäring på. Hela måldomänen och alla domänaspekterna av konstruktet kan inte testas vid ett enskilt tillfälle. Testande handlar, liksom all pedagogisk verksamhet, om urval. Kravet på urvalet uppgifter är att det ska vara relevant och representativt gentemot konstruktet och måldomänen. Detta är innehållsaspekten av validiteten. Även om vi vet att en prov-konstruktion aldrig kan vara valid i sig själv, kan studier av provverktyget kan ändå ha ett värde för valideringsarbetet. Dels genom att de kan bidra till en ökad variation i uppgiftskonstruktionen. Dels genom att de kan avtäcka rivaliserande hypoteser, det vill säga frilägga faktorer som potentiellt kan bidra till resultatvariation som inte låter sig förklaras av konstruktet (jfr Messick 1989:50f). 


\section{Skrivprov som textkulturellt påbud}

Det jag i den här studien söker göra är att ur testdomänen dels rekonstruera det idealtypiska konstrukt och de måldomäner som provkonstruktionen bygger på, och dels teckna en bild av hur dessa samplas. Det perspektiv jag anlägger på testdomänen hämtar jag från den antropologiska textteori som utvecklats av Berge $(2001,2008,2013)$ och Ledin $(2000,2013)$. Utgångspunkten är att en text är ett yttrande som medierar världen på ett sätt som tillskrivs ett särskilt värde $i$ en kultur. Vilka yttranden som räknas som text och hur sådana yttranden ska vara ordnade är med andra ord normativt konstituerat i sociala gemenskaper som utgör textkulturer. Att bli skrivkunnig innebär med denna syn att tillägna sig de olika skrivredskap som krävs för ett relevant deltagande i textkulturen. Liksom den högre utbildningen består av olika ämnesgemenskaper, som normerar vilka medieringar som är relevanta för att handla i gemenskapen och göra världen begriplig på (jfr Blåsjö 2004) består skolan av olika textkulturer. De naturvetenskapliga ämnena har sina textbegrepp (af Geijerstam 2004, Nygårds Larsson 2011), liksom historieämnet och matematikämnet har sina osv. Att lära sig skriva innebär med denna syn att lära sig använda skriften och andra semiotiska resurser för att mediera på sätt som gör ens skrivhandlingar textkulturellt värdesatta.

För att förstå text är yttrandet en nödvändig utgångspunkt. Yttranden är ögonblicksverk och möjliga att förstå och respondera på för deltagare i kommunikationen genom principen för inten-tionalitet. Intentionalitet är det som gör att vi förstår när någon pratar till oss att denna någon vänder sig till oss, att denne någon vill något, och att det är menat att vara relevant $i$ den unika situationen. Ett annat sätt att uttrycka det är att intentionalitet summan av den handling och det syfte ett yttrande realiserar. Varje text är ett yttrande, och förstås som sådant utifrån kännedom om den unika situationskontexten. Men för att förstås som text måste de också förstås utifrån de större institutionella, sociohistoriska sammanhang de verkar i, det vill säga utifrån en eller annan kulturkontext. Ska ett yttrande förstås som text måste skribenten ha tillgång till den kulturellt ela-borerade intentionalitet som bestämmer hur handlingen ska utföras för att förstås och fullgöra sitt syfte i kulturkontexten.

Kulturellt elaborerad intentionalitet kan kodas i flera semiotiska dimensioner i en text. En sådan är materialiteten som när den formateras kan knytas till en kulturell förförståelse, som tillsammans med inskriptionens yttre form fenomenologiskt gör läsaren medveten om texten som text (Ledin 2013). Så vet alla med erfarenhet från skolan att ett provpapper (med dess förtryckta fält för namn, klass och betyg) som har en handskriven och till det yttre sammanhängande inskription troligen är en elevuppsats. En annan dimension är genre. Genrer är konventionaliserade sätt att lösa återkommande retoriska situationer (Miller 1984). Typiskt innefattar genrer en konventionaliserad inre struktur, en viss stil och ett visst innehåll, och typifieras av brukarna (Swales 1990). En tredje dimension utgörs av Ecos (1994) begrepp modellskribent och modelläsare. Modelläsaren är den idealtypiske mottagare som skribenten förutser och genom yttrandet skapar. Det är medvetenhet om modelläsaren som gör att vi som empiriska läsare vet var vi ska 
skratta i en seriestripp, även när vi av endera anledningen inte är mottagliga att inta positionen. Med Eco modelleras på motsvarande vis skribenten textinternt, i form av den röst som manifesteras genom den narrativa strategi som vi måste följa om vi vill agera som modelläsare. Vidgar vi detta till sakprosa manifesteras modellskribenten genom de globala linjära och hierarkiska strukturer och ramar som yttrandet aktualiserar (jfr Berge 2013:82f). Så kan den empiriske läsaren ikläda sig rollen som modelläsare och se hur exempelvis argumentationen i ett skriftligt yttrande hänger ihop även när hon inte håller med om den tes yttrandet uttrycker. Ska yttrandet räknas som text behöver modellskribentens röst svara mot kulturellt accepterade skribentpositioner. En textkultur normerar med andra ord en uppsättning skribent- och läsarpositioner, sociala roller som de kompetenta deltagarna ikläder sig genom att agera modellskribent och modelläsare i texter.

Svenskämnets provkonstruktion erbjuder genom sina uppgifter olika möjligheter att yttra sig. Samtidigt är valfriheten som erbjudandena skapar begränsad, och varje elev är ålagd att välja en uppgift. Summan av erbjudandena är därför ett påbud som sätter gränser för vad som är att betrakta som text inom de nationella proven. Provkonstruktion normerar så en provintern textkultur (det som kan ske inom konstruktionens testdomän), som hämtar legitimitet från - och förutsätts ha bäring på - en eller annan textkultur utanför proven (konstruktionens måldomän/er). Ett självklart drag i den provinterna textkulturen är att eleven skriver för att visa upp sin förmåga att skriva och få produkten bedömd av läraren. Det jag intresserar mig för är vad proven normerar textuellt innanför denna ram. Ett krav på det som sker innanför denna ram kan kopplas till den grundläggande betygsgrundande rationaliteten. Det som ska tas med i ett prov är sådana uppgifter som diskriminerar mellan prestationsnivåer (Messick 1989:38). Om uppgifterna inte diskriminerar mellan prestationsnivåer kan resultaten inte göra det de ska göra: stödja betygssättning. Likafullt finns möjlighet till stor variation gällande vilka handlingar, former, ämnen och skribentroller uppgifterna kan pröva. Eller annorlunda uttryckt finns det många tänkbara medieringar som en provkonstruktion kan ge särskild status som belägg för måluppfyllelse. De textkonstituerande gränser som proven de facto ställer upp, och som denna undersökning söker belysa, tycks i stor utsträckning delas av svensklärarna, som i regel uppfattar provens uppgifter som relevanta gentemot den egna praktiken. Detta framkommer bland annat i lärarenkäter från de provomgångar som undersöks i den här studien (Provkonstruktionsgruppen 2007, 2008, 2009, 2010, 2011 samt 2012).

\section{Provkonstruktionens upplägg och anspråk}

På den nationellt bestämda provdagen möter eleverna åtta eller nio skrivuppgifter, och de har 5 timmar på sig att välja en uppgift och skriva sin text utifrån den. Med sig har de ett texthäfte där autentiska debattartiklar, reportage, kulturartiklar från olika medier, utdrag ur fackböcker och romaner, samt dikter och bilder samsas. Texthäftet belyser ett provspecifikt tema såsom 
"Moderna tider" (vårterminen 2007), "Engagemang och påverkan" (vårterminen 2009) och "Tecken och signaler" (vårterminen 2011). Provskrivandet är avslutningen på en process som läraren, utifrån en bedömning av elevernas behov, har möjlighet att påbörja tre till fyra veckor före utsatt provdatum. Eleverna ska under denna tid få möjlighet att bekanta sig med texthäftet och få tillgång till reflektionsfrågor över provtemat. Till sitt förfogande har läraren också ett kopieringsunderlag från provmaterialet. Detta omfattar allmänna skrivråd om inledningar och hur man gör källhänvisningar funktionellt och formellt, en typologi med generiska beskrivningar över olika uppgiftstyper, bedömda och kommenterade exempeltexter, samt en uppgiftsgenerisk matris.

Läraren har vidare dels allmänna bedömningsanvisningar för provtext, dels specifika för provomgångens uppgifter. Dessa består av kommentarer till uppgifterna, uppgiftsspecifika matriser, och till varje uppgift också två till tre bedömda och kommenterade exempellösningar som representerar olika betygssteg. Vid bedömningen förordas en holistisk modell, och matriserna är mer att betrakta som stöd än som analytiska checklistor som summerar betyg.

Svenskämnets prov är, som sagt, framtagna för att mäta ett konstrukt som finns i kursplanen, snarare än ett grundat i någon särskild skrivteori. Samtliga skrivuppgifter gör anspråk på att pröva följande mål i kursplanen för Svenska B:

Eleven

kan "förmedla egna och andras tankar i ... skrift, göra sammanställningar och utredningar samt dra slutsatser och föra fram argument, så att innehåll och budskap blir tydliga och anpassade till målgrupp och syfte"

har "utvecklat skrivandet som medel för tänkande och lärande"

(Bedömningsanvisningar 2012:1)

Vissa av skrivuppgifterna betraktas som relativt komplexa, och i dessa görs även anspråk på att pröva följande mål i kursplanen:

Eleven

kan "jämföra och se samband mellan litterära texter från olika tider och kulturer"

(Bedömningsanvisningar 2012:1)

Dessa mål rymmer en mängd både uttalade och outtalade aspekter av skrivkonstruktet som undervisningen och provkonstruktionen har att ta hänsyn till. De uttalar att skrivande är situerad handling där skribenten för fram ett budskap/innehåll till en målgrupp, antyder några syften som att organisera ett stoff, utreda en eller annan fråga eller att argumentera. De säger mindre om vilka ämnen/frågor - förutom litterära texter - eleverna ska skriva, vilka roller de ska kunna inta, vilka målgrupper de ska kunna vända sig till, och om/hur detta ska inverka på resultaten.

E. Borgström

$9 / 34$ www.journals.uio.no 
Det första av de tre målen är det som tydligast präglar provkonstruktionen i stort. Skrivelsen att "förmedla egna och andras tankar i skrift" konkretiseras genom att majoriteten av uppgifter kräver att eleverna använder och hänvisar till röster i texthäftet, och begreppet "textanvändning" är ett eget kriterium vid bedömning. I sin helhet uttrycker emellertid provkonstruktionen att åter-givandet av andra röster snarare är en implicerad kvalitetsstandard än ett konstituerande drag i det skrivkonstrukt man gör anspråk på att mäta. Varje provupplaga har minst en skrivuppgift som inte kräver textanvändning. Dessa uppgifter betecknas vanligtvis som "mindre komplexa" och betygsskalan är avgränsad till IG-VG. ${ }^{2}$ De uppgifter som kräver hänvisning till häftet uttrycker två krav: dels att hänvisningen ska vara formellt korrekt, dels att innehållet som refereras är korrekt. Dessa är dock inte absoluta. I undantagsfall kan "en lösning som utnyttjar källor men saknar direkta hänvisningar godkännas om den i övrigt uppfyller de krav som ställs." Omvänt visar de kommenterade exempellösningar som materialet att en lösning som återger ett innehåll felaktigt men med en formellt korrekt källhänvisning ändå kan erhålla betyget $\mathrm{G}$.

Den andra delen i målet, att "göra sammanställningar och utredningar samt dra slutsatser samt föra fram argument", handlar olika texttyper. Texter kan med provens förståelse vara antingen berättande, utredande eller argumenterande. ${ }^{3}$ Varje uppgift prövar inte elevens förmåga att skriva alla texttyper, utan påbjuder i praktiken en utredande eller argumenterande texttyp. För betygssättningen uppmanas läraren att ha en elevportfölj: "Om en elev $i$ det nationella provet till exempel skrivit en argumenterande text, har läraren i elevens portfölj också de berättande och utredande texter som eleven åstadkommit" (Lärarinformation 2012:4). Uppdelningen mellan argumenterande och utredande återkommer i kopieringsunderlaget som beskriver de olika upp-giftstyper proven använder. Den återkommer också i den generiska beskrivningen av hur texterna ska bedömas. Där delas texter upp i resonerande/analyserande respektive argumenterande. Den förra uppgiftstypen beskrivs som följer:

I en resonerande och analyserande uppgift förs vanligtvis ett allmänt eller övergripande resonemang, och de påståenden som framförs bör illustreras med konkreta exempel. Omvänt bör ett konkret innehåll, såsom förslag till förbättringar i någon fråga, stärkas genom ett övergripande resonemang, till exempel att gemensamma drag hos de framförda förslagen betonas.

(Lärarinformation 2012:14)

\footnotetext{
${ }^{2}$ I det material som undersöks i den här studien finns också två uppgifter där hela betygsskalan upp till MVG kan användas, utan att uppgiften ställer krav på hänvisning till just texthäftet. I dessa uppgifter ska eleven skriva en recension av en actionfilm respektive en relationsfilm.

${ }^{3}$ Att just dessa tre texttyper tas upp kan förstås i ljuset av en lång tradition i svenskämnet, som för det skönlitterära berättande skrivandet till grundskolan, medan skrivundervisningen på gymnasieskolan istället bör behandla diskursiv framställning, det vill säga saksorienterad utredning/argumentation (jfr Hultman 1989:135f)

E. Borgström

$10 / 34$

www.journals.uio.no
} 
Den argumenterande uppgiftstypen ställer explicita krav så att stegen tes och argument måste ingå:

En argumenterande text måste innehålla en tes och argument. Innehållet bör bygga på ett visst mått av självständiga tankar eller iakttagelser.

(Bedömningsanvisningar 2012:14)

Den tredje delen i målet säger att texten ska anpassas till målgrupp och syfte. Här kan en kluvenhet i provkonstruktionen skönjas, som jag återkommer till. Varje uppgift tecknar en skrivsituation, med den publiceringsplats texten ska fungera i. Anpassning till situationen betonas i lärarmatriser och bedömningsanvisningar som den viktigaste aspekten att ta hänsyn till vid bedömning: "Först och främst bedöms lösningarna $i$ sin helhet, det vill säga att texten bedöms efter hur väl den fungerar i den angivna situationen" (Lärarinformation 2012:14). Detta preciseras så att "efterfrågad genre bör vara väl uppfattad, att budskapet går fram till läsaren och att omfånget är anpassat till situationen" (Lärarinformation 2012:14). Bedömningsanvisningarna betonar dock med fet stil att det är ett annat moment i skrivuppgiften som i slutändan är avgörande för om en elevlösning ska kunna godkännas, nämligen om eleven följer den instruktion som avslutar skrivuppgiften, och som normerar hur situationen ska hanteras. Att en text inte löser instruktionens alla led är det enskilt vanligaste huvudargumentet till IG bland exempellösningarna. Provkonstruktionen vilar med andra ord på antagandet att symmetri råder mellan förmågorna "att kunna anpassa sin text till konceptuell situation och målgrupp" och "att följa en skrivinstruktion".

\section{Material och analytiska ingångar}

Det material som ligger till grund för undersökningen består av vårterminsproven från åren 20072012. Totalt omfattar materialet 52 stycken skrivuppgifter. De textkulturella dimensioner som jag analyserar uppgifterna ur är tema, inre struktur, grundhandling och skribentroll. Tillsammans ger de, menar jag, en god bild av de typer av skrivande som eleverna erbjuds inom proven, och har att förhålla sig till i sina texter (jfr resonemanget om balansering i Krogh \& Hobel 2013). Därmed fångar de centrala dimensioner i det aggregerade idealtypiska konstrukt som provkonstruktionen ger uttryck för. Analyskategorierna som faller under de olika dimensionerna är, med undantag för grundhandling, induktiva och har uppstått genom en längre tids umgänge med materialet. De olika grundhandlingskategorierna är deduktiva och utgår från de norska grundskoleprovens konstrukt Skrivehjulet.

De skrivuppgifter jag lyfter som exempel i resultatavsnittet återger jag i sin helhet (bortsett från att rubriken återupprepas och att betygsskalan står utskriven i originalen). Jag etiketterar dem med dels årtal, dels deras interna numrering, så att " $11 B 8$ " står för vårterminen 2011, delprov B, uppgift 8. Uppgifterna följde en tydlig stöpform under hela den undersökta perioden. 
Med utgångspunkt i följande specifika uppgift som exempel presenterar jag denna form och hur de olika delarna tjänar som index för de analytiska dimensionerna:

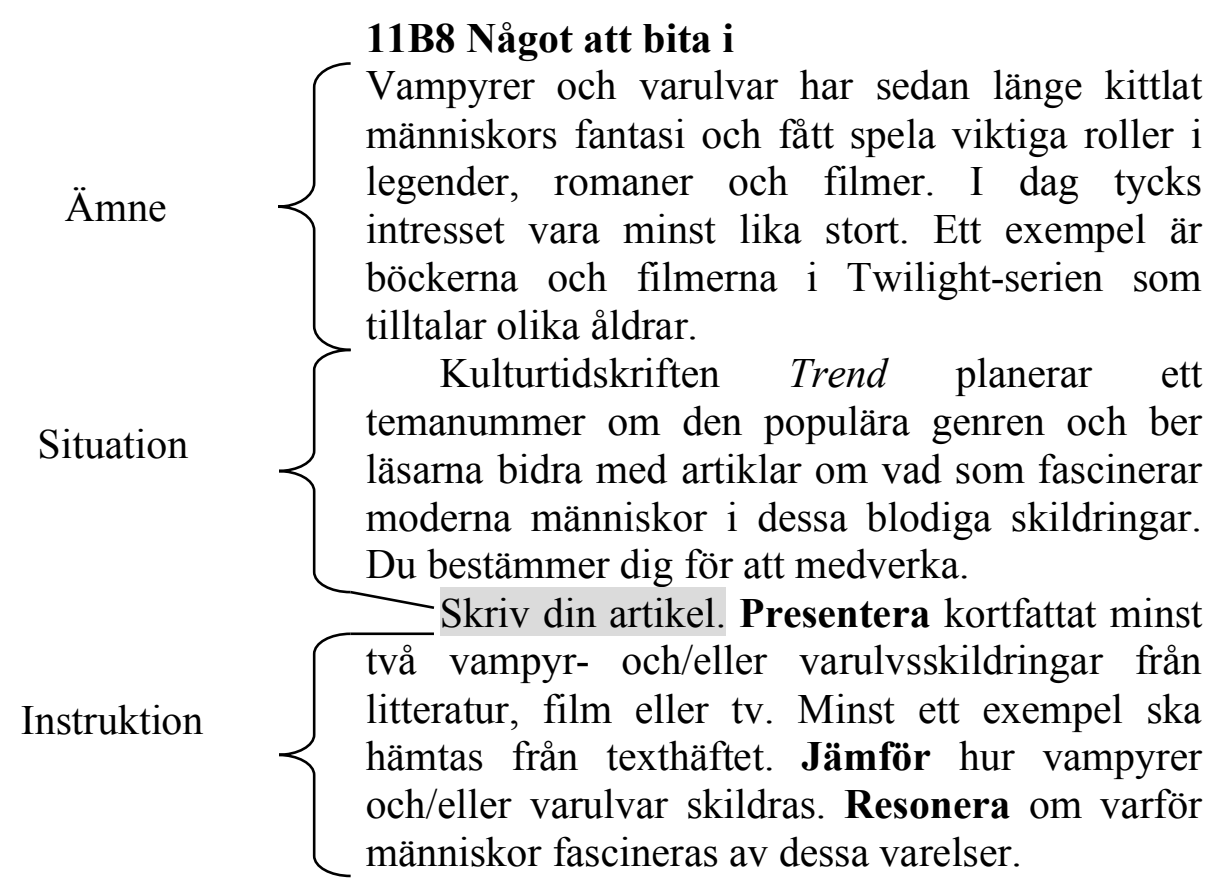

I varje uppgift möter eleverna först ett ämne, därefter en skrivsituation som innebär att eleven ska handla i skrift och anger ett publikationsforum där det som ska bli texten ska ingå. Slutligen ges en instruktion som uttrycker formella och innehållsliga förväntningar på hur handlingen ska hanteras.

Kategoriseringen av teman tar sin utgångspunkt i de ämnen uppgifterna ger. I uppgiften ovan är ämnet människors fascination för den litterära genre som kretsar kring blodsugarväsen. När uppgiftssamplet studeras $i$ helhet låter sig denna uppgifts specifika ämne förstås som ett exempel på ett återkommande tema, som jag kallar kultur och människa. Detta tema rymmer uppgifter om människa och semiotiska eller teknologiska fenomen, som exempelvis gruppspråk, kläder eller modern kommunikationsteknologi, men också uppgifter om litterära verk, motiv och genrer. Ett annat återkommande tema $\mathrm{i}$ provkonstruktionen kallar jag moralladdade samhällsfrågor. Upp-gifter som faller under detta tema intar ett generiskt perspektiv på exempelvis skilsmässor, mång-gifte och yngres arbetsmoral. Ett fåtal uppgifter som handlar om vetenskap och privatsfären faller under kategorin övrigt.

Analysdimensionen inre struktur utgår från provens uppdelning i texter som antingen utredande eller argumenterande. Som index använder jag uppgifternas instruktionsled som består

E. Borgström www.journals.uio.no 
av ett antal uppmaningar, varav tre med fetstilta språkhandlingsverb. I vår vampyruppgift ska eleven först presentera ett par vampyr- eller varulvskildringar, därefter jämföra hur varelserna skildras och slutligen resonera om orsaken till människors fascination inför dessa väsen. Dessa vilar på en idé om global linjär struktur (jfr Borgström 2010), och gör tre steg obligatoriska att följa. Vampyruppgiften normerar en struktur som ligger nära den prototypiska utredande struktur som på ett generiskt plan ser ut såhär:

Tabell 1. Prototypisk stegvis struktur i utredande uppgifter.

$\begin{array}{ll}\text { Steg } 1 & \text { Presentation/Exemplifiering } \\ \text { Steg } 2 & \text { Analys } \\ \text { Steg } 3 & \text { Slutsats/Ställningstagande }\end{array}$

I utredande uppgifter normeras vanligtvis åtminstone två av ovanstående steg. I instruktionens första led tas avstamp i det specifika, med att presentera eller ge exempel på ett fenomen. I mittledet har vi typiskt en analytisk uppmaning, där en organiseringsprincip ofta anges, så som komparation, kausalitet, konsekvens eller evaluering. Den sista uppmaningen implicerar ofta - som i vampyruppgiften ovan - den fråga som är föremål för utredning i texten som helhet, och renderar typiskt i steget generell slutsats, eller ställningstagande. Den utredande instruktionstypen hör samman med genrenamn som artikel, essä, krönika, manus och inlägg (den gråmarkerade första uppmaningen i uppgiftsexemplet ovan). Till kategorin argumenterande uppgifter förs de där eleven i instruktionsledet först uppmanas att uttrycka ett ställningstagande, och därefter att argumentera för detta ställningstagande. Uppgifter med sådana instruktionsled kommer vanligtvis med genrenamn som debattinlägg och debattartikel. Kategoriseringen av inre struktur är dock gjord utan hänsyn till dessa genrenamn. Den analytiska dimensionen grundhandling kommer sig av att det textkulturella perspektivet implicerar att en text som helhet är en mediering av en handling i en social situation (jfr Wertsch 1993:12ff).

Jag förstår således varje uppgift som att den implicerar en dominerande skrivhandling, vilket jag kallar uppgiftens grundhandling. För att frilägga vilken grundhandling uppgiften implicerar använder jag det norska skrivkonstruktet Skrivehjulet (exempelvis Evensen 2010). Detta är framtaget med utgångspunkt i begreppet skrivande som grundläggande färdighet, och DeSeCo (2005): 


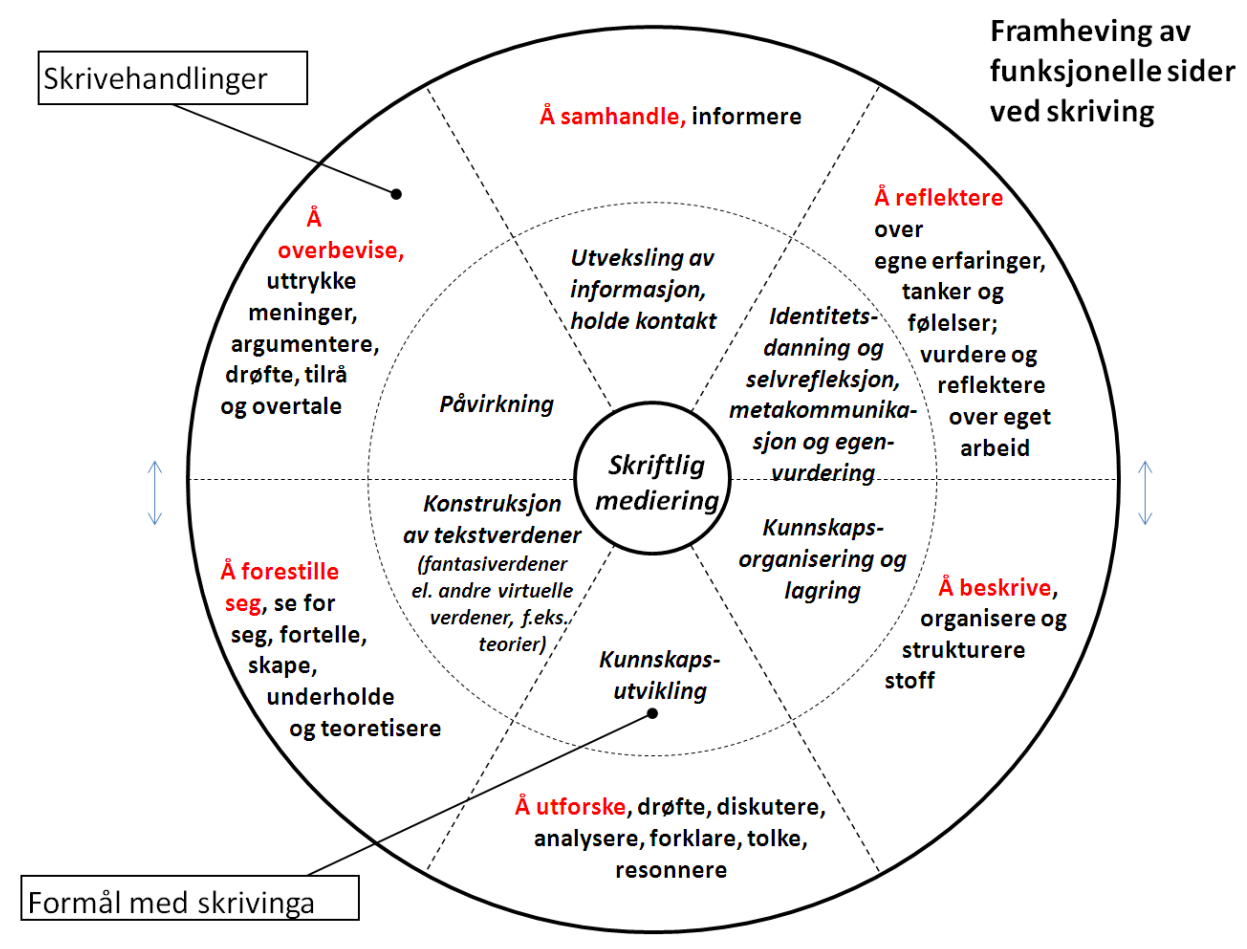

Figur 2. Skrivehjulet (http://www.skrivesenteret.no/ressurser/skrivehjulet/)

Utifrån idén att skrivande i vår västerländska kultur fyller sex grundläggande syften (den mellersta cirkeln) frilägger gruppen bakom konstruktet sex olika grundläggande skrivhandlingar (den yttersta cirkeln), som medieras i skrivandet. En skrivundervisning baserad på denna teori om skrivande som grundläggande färdighet låter elever i skolans alla ämnen få tillfälle att öva, och bedömas (formativt och summativt) i var och en av dessa skrivhandlingar. De olika handlingarna skiljer sig åt utifrån prototypiska syften i kulturen, och genom sin dominerande riktadhet mot antingen det skrivande jaget, den läsande andre eller mot referentialiteten, det vill säga det utsnitt av världen som medieringen pekar ut eller konstruerar. Modellen är idealtypisk och tänkt som ett redskap för framtagande av provuppgifter och vägledning för en ämnesbaserad skrivundervisning. Det betyder att de intentionaliteter modellen aktualiserar instansieras i praxis, det vill säga i ljuset av vilket ämnesstoff/innehåll i läroplanen som är föremål för undervisning och/eller bedömningsmoment.

Handlingarna preciseras närmare i Skrivehandlinger og skriveoppgaver (Normprosjektet 2012). Samhandling och övertygande skrivhandling är du-orienterade. I samhandling är ett centralt syfte att hålla kontakt, i övertygande är det vanligtvis att påverka mottagaren i en eller annan riktning. Den reflekterande skrivhandlingen är jag-orienterad, och syftar vanligtvis till identitetsbildning. De beskrivande, föreställande och utforskande skrivhandlingarna är det-orienterade, det 
vill säga mot en eller annan omvärld. I den beskrivande handlingen förutsätts fenomenet vara klart för skribenten, och skrivandet kan handla om att redogöra, definiera och exemplifiera eller systematisera kunskap. I den föreställande skrivhandlingen är skrivandet riktat mot ett tänkt eller fiktivt fenomen som skribenten skapar genom texten. Det må vara fiktionsvärldar, utopier, visioner eller teorier. Syftet är att skapa nya tänkta, önskade eller fiktiva verkligheter. Går vi tillbaka till uppgiften om vampyrer ovan, kategoriserar jag den utifrån skrivehjulets beskrivningar som utforskande. Den utforskande skrivhandlingen är det-orienterad, och riktad mot fenomen där kunskapen är osäker och måste göras sannolik. Exempelvis kan man dryfta, tolka, resonera, eller ställa etablerad kunskap i relation till egna erfarenheter. Syftet är primärt att utveckla ny kunskap, en ny förståelse av verkligheten. Detta stämmer väl med vår vampyruppgift ovan, som är tydligt det-orienterad, och förutsätter en skribent som genom att resonera söker utveckla kunskap om möjliga orsaker till fascinationen för vampyrgenren.

I den här undersökningen använder jag skrivehjulet för att dra en analytisk gräns mellan den inre struktur uppgiften normerar och den handling uppgiften implicerar. En central poäng med skrivehjulet är att konfigurationerna mellan handling och syfte inte är låsta. Hjulet är vridbart så att man genom skriften kan föreställa sig i syfte att utveckla kunskap, eller strukturera ett stoff i syfte att påverka. På samma vis utgår jag ifrån att de nominella formkategorierna utredande och argumenterande text visserligen hänger nära samman med intentionalitet, men att de i sig själva inte etablerar en klar funktionell gräns. Den akademiska uppsatsen följer ofta den utredande formen, men vi kallar idealet för en argumenterande helhet (jfr Tirkonen-Condit 1985). Chatman (1990) menar även han i en diskussion av texttyper att argumentation och utredning båda är former som typiskt är övertygande. Skillnaden handlar snarare om föreställningar om läsaren än funktion, som i båda fallen är övertygande. Argumentationen som form, skriver Chatman (1990:207), tycks generellt förutsätta en läsare som är av en annan ståndpunkt i frågan, medan utredningen istället förutsätter frånvaron av en tydlig ståndpunkt hos läsaren. "Of course" skriver Chatman, "the clarification itself implies an argument about the preferability of that clarification, so the line between these two text-types is hazy" (1990:207).

Den sista dimension som analyseras är de återkommande skribentroller som eleverna erbjuds ikläda sig (jfr resonemanget om Ecos modellskribentbegrepp på s. 7-8). Skribentrollerna utgör en syntes av de övriga undersökta dimensionerna för varje uppgift, det vill säga tema, inre struktur och grundhandling, kombinerat med de aspekter av den fingerade skrivsituation som uppgiften aktualiserar - exempelvis publikationsforum, frivillighet etc. Så ger de olika skribentrollerna en summerande bild av de återkommande skrivsituationer - måldomänsuppgifter för att tala mätspråk - som uppgifterna som helhet aktualiserar. I vår vampyruppgift är skribentrollen en röst som tillhör en vanlig läsare av kulturtidsskriften Trend, som med journalistens auktoritet förklarar för andra gemene läsare av tidskriften varför människor i allmänhet fascineras av vampyrer. Denna röst är ett exempel på en återkommande skribentroll som jag kallar Den självutnämnda folkbildaren. Andra roller som återkommer är Den 
engagerade medborgaren, Den engagerade kulturkonsumenten och Eleven. Samtliga presenteras närmare och exemplifieras i resultatavsnittet nedan.

\section{Resultat}

I detta avsnitt presenterar jag resultaten genom att på olika vis korsa de angivna dimensionerna. Jag börjar med den dimension som proven själv sorterar skrivandet som domän på, nämligen inre struktur, vilket jag parar med analysen av uppgifternas grundhandling. Därefter korsar jag grundhandling med den tematiska dimensionen och presenterar slutligen fördelningen av de skribentroller proven erbjuder. Varje avsnitt inleds med en kvantitativ presentation av uppgiftssamplet. Jag strävar efter att ge gott om exempel på både det jag betecknar som typiska som tveksamma fall, för att ge läsaren möjlighet att ta ställning till mina tolkningar. Alla exempel jag tar upp är hela bedömningsskalan aktuell, dvs IG-MVG. Kategoriseringarna har gjorts två gånger med ett halvårs mellanrum, vilket enbart inneburit smärre justeringar, som inte påverkat dominansmönstren.

\section{Inre struktur och grundhandling}

En översiktlig sammanställning över uppgiftssamplet fördelat på inre struktur och grundhandling ges i tabell 2. Jag går först igenom typfallen, och går avslutningsvis in närmare på undantagen från mönstret:

Tabell 2. Skrivuppgifterna fördelade på inre struktur och grundhandling

\begin{tabular}{lllllll}
\hline StrukturlGrundhandling & $\begin{array}{l}\text { Att } \\
\text { utforska }\end{array}$ & $\begin{array}{l}\text { Att } \\
\text { övertyga }\end{array}$ & $\begin{array}{l}\text { Att } \\
\text { reflektera }\end{array}$ & $\begin{array}{l}\text { Att } \\
\text { föreställa } \\
\text { sig }\end{array}$ & $\begin{array}{l}\text { Valbar } \\
\text { (utforska/övertyga) }\end{array}$ & Total \\
\hline Utredande & 24 & 9 & 1 & - & 6 & 40 \\
Argumenterande & & 9 & - & - & - & 9 \\
Övrigt & & 2 & & 1 & - & 3 \\
\hline Total & 24 & 20 & 1 & 1 & 6 & 52 \\
\hline
\end{tabular}

Som synes dominerar den utredande inre strukturen, som normeras i fyrtio uppgifter, framför den argumenterande som återfinns i nio uppgifter. Går vi till grundhandlingarna ser vi att den utforskande handlingen är vanligast med 24 stycken uppgifter, och att den är tätt följd av den övertygande handlingen, vilken impliceras i 20 stycken uppgifter. När strukturkategorier och handlingskategorier korsas ser vi tre typfall. Uppgifter som implicerar utforskande handling normerar uteslutande utredande struktur. Omvänt ser vi att de uppgifter som normerar en argumenterande struktur alltid implicerar övertygande handling. Lika vanligt är dock att den övertygande handlingen ska medieras i den utredande strukturen (vilket är anledningen till att materi- 
alet är jämnare fördelat handlingsmässigt än strukturmässigt). Dessa tre typfall ska jag nu ge exempel på, och vi börjar med följande uppgift:

\section{B8 Ljuset i biomörkret}

Filmens inverkan är välkänd, men ofta diskuteras de negativa konsekvenserna snarare än de positiva. Forskaren Tomas Axelson har visat att film också ger många människor upplevelser som berikat deras liv och fått dem att se sig själva med nya ögon.

Filmtidningen Cinema ber läsarna skriva om betydelsefulla filmupplevelser och du bestämmer dig för att skicka in en krönika. En krönika är en personligt hållen text om något aktuellt ämne som kan intressera många.

Skriv din krönika. Utgå från en film som påverkat dig positivt och precisera vad det är i filmen som gjort intryck. Presentera några tankegångar som finns $i$ artikeln om Tomas Axelsons forskning och diskutera hur film kan påverka åskådaren.

Instruktionen ger vid handen att eleven ska ta utgångspunkt i egna erfarenheter och ställa dessa $\mathrm{i}$ relation till forskning som presenteras i texthäftet, för att slutligen föra ett generiskt resonemang om hur filmen kan påverka åskådaren. Den överordnade handlingen som jag tolkar att uppgiften implicerar är att utforska filmens positiva effekter på tittaren, och handlingen ska medieras i en utredande inre struktur.

Följande uppgift är ett typiskt exempel på där handlingen är att övertyga och formen är argumenterande text:

\section{B1 Latoxar och arbetsmyror}

Tv-programmet Ung och bortskämd skapade stor debatt när det sändes i Sverige. Efter det har många fortsatt att hävda att dagens unga är lata och har sämre arbetsmoral än äldre. Andra hävdar tvärtom att unga är mycket målmedvetna och beredda att ta $\mathrm{i}$. Arbetskraftsutvandringen till Norge tas ibland upp som ett bevis för det.

I din lokaltidning pågår en debatt om arbetsmoral, och du bestämmer dig för att bidra med ett debattinlägg om ungdomars inställning $\mathrm{i}$ frågan.

Skriv ditt debattinlägg. Ta ställning $i$ frågan om dagens unga har sämre arbetsmoral än äldre generationer och argumentera för din åsikt. Jämför med synpunkter hämtade ur texthäftet. 
Här ska eleven delta $i$ en debatt $\mathrm{i}$ lokaltidningen, och instruktionen ger vid handen att eleven ska ta ställning och argumentera och förhålla sig till de synpunkter och åsikter som finns i ämnet i texthäftet. Eleven ska alltså övertyga läsaren om att den egna beskrivningen av ungas arbetsmoral är giltig, och mediera denna handling $i$ en argumenterande inre struktur.

I lika många uppgifter där handlingen är att övertyga normeras alltså istället en utredande inre struktur. Här följer ett exempel på en sådan:

\begin{abstract}
09B6 Utlämnad?
I tv-program som Idol utsätter sig unga människor för granskande blickar och kritiska kommentarer. Ändå vill många medverka. På YouTube, Facebook och MySpace finns uppgifter om och bilder på människor som exponeras, ibland ofrivilligt. Trots detta ökar antalet användare.

På webbplatsen svt.se/opinion diskuteras hur människor visas $\mathrm{i}$ media och på webben $\mathrm{i}$ dag. Du bestämmer dig för att delta $\mathrm{i}$ diskussionen. Webbplatsens redaktör efterfrågar artiklar på 500-800 ord.

Skriv in webbartikel. Ge exempel på hur människor synliggörs $i$ media och/eller på webben. Använd texthäftet och diskutera konsekvenserna av de nya möjligheterna att synas. Ta själv ställning i frågan.
\end{abstract}

Den inre struktur som instruktionen normerar är den typiskt utredande, med stegen att utgå från exempel, därefter diskutera konsekvenser och slutligen själv ta ställning till fenomenet. Uppgiften som helhet implicerar att handlingen är övertygande; eleven tar genom texten ställning och deltar på så vis i en offentlig diskussion, som denna gång förs på SVT:s opinionsportal. Detta implicerar att eleven genom sin utredning ska övertyga läsaren i frågan om samtidens stora möjligheter för människor att synas i offentligheten övervägande har positiva eller negativa konsekvenser.

Ett fătal uppgifter sticker ut sett till dimensionerna inre struktur och grundhandling. Endast tre stycken uppgifter har inte kunnat kategoriseras utifrån tolkningspremisserna för dimensionen inre struktur och faller därför i raden "Övrigt" i tabell 2. Två av dessa implicerar grund-handlingen att övertyga, men instruktionerna normerar inte entydigt den utredande eller argu-menterande struktur, utan endera strukturen tycks möjlig. Omvänt gäller för de sex utredande uppgifter som faller i grundhandlingskategorin "Valbar". Där är det snarast så att eleven tycks ha att välja om den utredande formen ska användas för mediera en utforskande eller övertygande handling. En utredande uppgift har jag kategoriserat som reflekterande grundhandling. Den handlar om varför man är supporter och hur man visar det, och kategoriseringen som reflekterande baserar jag på uppgiftens tydliga jag-centrering; den 
fokuserar elevens egen supporteridentitet och kräver att eleven medierar reflektioner över personliga erfarenheter.

Det verkliga undantaget från mönstret utgör dock följande uppgift, som både faller utanför kategorierna utredande/argumenterande, och som jag kategoriserat som den i proven avvikande grundhandlingen att föreställa sig:

\section{B8 Kärleken - störst av allt?}

Är det sant att kärleken är så himlastormande som den beskrivs i konst och litteratur?

Föreställ dig att du är reporter på tidskriften Tillsammans och får i uppdrag att skriva ett reportage där du skildrar förälskade människor och deras upplevelse av kärleken. Tänk dig att du intervjuar en eller båda parter $\mathrm{i}$ ett par som förekommer $\mathrm{i}$ någon text eller bild $\mathrm{i}$ texthäftet. Intervjun kan tänkas äga rum i den tid som skildras eller vid en annan tidpunkt. Använd fantasin när du skildrar parets syn på kärleken i ditt reportage men försök också fånga den stämning och känsla som förmedlas i verket. Ett reportage är personligt skrivet, har ett visst nyhetsvärde och låter den intervjuade själv träda fram.

Skriv ditt reportage. Beskriv kärleksparet som förekommer i den text eller bild du valt och gör en tolkning av vilka personerna är. Skildra med utgångspunkt från en tänkt intervju hur en eller båda parter ser på kärleken. Tänk på att reportaget ska fånga verkets budskap och stämning.

Uppgiften efterfrågar sett till inre struktur ett slags dokumentär gestaltning, och är intressant sett till dimensionen grundhandling. Uppgiften har fiktionsnivåer, som övriga saknar, och det som ska framställas som dokumentärt är i själva verket fiktion. Sett till den fiktiva situation som tecknas och rubriken för texten är grundhandlingen som efterfrågas snarast att utforska frågan om kärleken är så fantastisk. I provsituationen är den handling eleven medierar genom skrivandet dock inte att utforska utan att föreställa sig - att fantisera fram en textvärld. Detta är den enda uppgift där läraren måste bedöma elevens text som om den vore en realisering av annan grundhandling än vad provsituationen de facto kräver.

\section{Tema, grundhandling och struktur}

Provuppgifternas ämnen kan som nämnt i huvudsak föras till två olika typer av teman, nämligen Kultur och människa, och Moralladdade samhällsfrågor. Grundhandlingarna samvarierar med de teman som uppgifterna ger, vilket åskådliggörs i tabell 3: 
Tabell 3. Skrivteman fördelade på grundhandlingar

\begin{tabular}{lllll}
\hline GrundhandlinglTema & $\begin{array}{l}\text { Kultur och } \\
\text { människa }\end{array}$ & $\begin{array}{l}\text { Moralladdade } \\
\text { samhällsfrågor }\end{array}$ & Övrigt & Total \\
\hline Att utforska & 20 & 1 & 3 & 24 \\
Att övertyga & 6 & 14 & & 20 \\
Övrigt & 3 & 2 & 3 & 8 \\
\hline Total & 29 & 17 & 6 & 52 \\
\hline
\end{tabular}

Utforskande uppgifter handlar företrädesvis om kulturella fenomen. De flesta av dessa uppgifter går ut på att utforska relationen mellan människan och något semiotiskt eller teknologiskt fenomen, som exempelvis gruppspråk, kläder eller modern kommunikationsteknologi. I dessa uppgifter står bruket av fenomenet snarare än fenomenet i egen rätt i fokus, och inte sällan brukets orsaker och konsekvenser i termer av människors identitet eller livsvillkor. I kategorin utforskande kulturuppgifter finns även ett mindre antal uppgifter som fokuserar kulturformer som litterära verk, motiv och genrer i egen rätt. Dessa uppgifter kan handla om att utforska litterära naturskildringar, allegorier eller arketyper. I materialet finns också tre stycken utforskande uppgifter som faller utanför gängse teman. Dessa handlar om vetenskap och privatliv. Uppgiftssamplet rymmer också sex stycken övertygande kulturuppgifter. Här handlar det exempelvis om att ta ställning och övertyga läsaren om exempelvis verklighetsbaserade eller fiktiva romaner är bäst, om live-föreställningar eller inspelade föreställningar ger bäst upplevelse, eller att genom en recension övertyga läsaren att se en särskilt bra relations- eller actionfilm.

Övertygande uppgifter vetter annars oftast åt moraliskt laddade samhällsfrågor. De handlar om vittnesplikt, skilsmässa, generationers värderingar, våld bland pojkar och män, ungdomars arbetsmoral och så vidare. Ämnena har som synes ofta tydliga kopplingar till intimsfär och privatliv, men behandlas i uppgifterna som generiska samhällsfrågor, vilket också är det perspektiv eleverna ska anlägga. Samtliga övertygande uppgifter som normerar formen argumenterande text handlar om denna typ av samhällsfrågor. De sex övertygande kulturuppgifterna som nämndes $\mathrm{i}$ föregående stycke normerar istället alla den utredande strukturen.

Endast en uppgift av dem jag har jag kategoriserat som utredande och implicerande en utforskande grundhandling handlar innehållsligt om en moraliskt laddad samhällsfråga. Denna uppgift är följande:

\section{B7 En höna av en fjäder}

Många kändisar och officiella personer jagas av fotografer, så kallade paparazzi, och journalister som är ute efter en nyhet eller bild att sätta på löpsedlarna. Det finns också aktuella fall där journalister spårat upp obekväma sanningar om personer vilka sedan tvingats be om ursäkt eller till och med avgå. 
Det är viktigt med pressfrihet men hur långt får media gå i sitt uppdrag att skildra aktuella händelser? Detta ska diskuteras i tvprogrammet Kalla fakta och redaktionen ber om tittarnas synpunkter till programmets webbplats.

Skriv ditt debattinlägg. Ge med hjälp av texthäftet och eventuellt egna erfarenheter exempel på hur rykten blir nyheter. Diskutera hur medier hanterar enskilda personer och deras integritet. Kommentera positiva och/eller negativa följder av mediebevakningen.

$\AA$ ena sidan kan denna uppgift tyckas implicera att eleven ska övertyga, kanske till och med genom argumenterande text. Vi har ett ämne som ska diskuteras i offentligheten, vi har tv-tittare som ombeds att ge synpunkter och eleven väljer att/ska skriva ett debattinlägg. Å andra sidan har vi ett instruktionsled som genom sina uppmaningar aktualiserar den utredande strukturen. Till det kommer att ämnet famnar över tämligen skilda fenomen, som paparazzis bevakning av kändisar och journalisters granskning av officiella personer i maktposition. Mot den bakgrunden menar jag att uppgiften som helhet därför vetter åt att genom en utredning utforska de etiska gränserna för vad som är att betrakta som legitim mediebevakning. ${ }^{4}$

\section{Skribentroller}

Proven etablerar i huvudsak fyra olika skribentroller - tänkta röster med vilka eleven ska skriva. Dessa fördelar sig i materialet som följer av tabell 4 :

Tabell 4: Erbjudna skribentroller i uppgiftssamplet

\begin{tabular}{ll}
\hline Skribentroll & Antal \\
\hline Den självutnämnda/(efterfrågade) folkbildaren & $22 /(+4)$ \\
Den engagerade medborgaren & 11 \\
Den engagerade kulturkonsumenten & 6 \\
Eleven & 3 \\
Övriga & 6 \\
Total & 52 \\
\hline
\end{tabular}

Den självutnämnda folkbildaren är som synes den vanligaste. Den empiriska skribenten som ikläder sig denna roll är vanligen en läsare - kulturintresserad sådan - av någon tidning eller tidskrift. Det handlar om lokaltidningen, någon kulturmyndighets hemsida, en kulturtidskrift eller ungdomstidning. Undantagsvis kan folkbildaren också vara en elev som skriver i skoltidningen. Rollen uppstår vanligtvis genom att publiceringsforumet efterfrågar skribenter på ett ämne. Ibland, som när Utbildningsradion ber gymnasieelever skriva om språk och identitet för hem-

\footnotetext{
${ }^{4}$ Ett liknande resonemang om relationen instruktion och genrebeteckning förs av provkonstruktörerna (Skolverket 2011:70f) gällande uppgift "B1 I nöd och lust" från 2010. Eleverna skulle skriva en debattartikel om skilsmässa, men texterna blev utredande vilket lärare uppfattat som problematiskt.
}

E. Borgström 
sidan i samband med en ny programserie (11B1), tycks publicisten ha didaktiska avsikter med att upplåta publiceringsplats. Ibland överlåter publicisten ett professionellt journalistiskt uppdrag på läsarna, av oklar anledning. När situationen uppstår drar sig inte den självutnämnda folkbildaren för att genom skriften med auktoritet upplysa andra medborgare om sakernas tillstånd, betydelser, orsaker och konsekvenser. Den självutnämnda folkbildaren utforskar fenomen genom utredning och refererar till andra texter på ämnet. Rollen är ett embryo till modellskribent, som den elev som lyckas ikläda sig rollen skapar i sin text. Eleverna förutsätts kunna skriva utforskande kring kultur och människa på generiska vis, och rikta denna text till läsare, som formellt befinner sig på samma nivå (och ibland rimligen är medveten om att skribenten är gymnasieelev). Så konstruerar uppgifterna inte bara en målgrupp (dvs läsaren av det aktuella mediet) utan också en idé om en modelläsare till den goda elevlösningen. Denna modelläsare är både mindre kunnig men intresserad av att förstå det givna fenomenet bättre, och därtill villig att acceptera att en annan vanlig person (icke-expert) ändå är värd att lyssna till. Ett exempel är som nämnt vampyruppgiften jag tog upp på sidan 12. Ett annat är följande, där Moderna museet gör plats på scen för skribentrollen:

\begin{abstract}
07B9 Konsten i det moderna samhället
Kring det förra sekelskiftet förändrades och förnyades litteraturen och bildkonsten dramatiskt. Konstnärer och författare ville göra sig fria från gamla tiders regler och synsätt. Resultatet kom att kallas modernism. Vilken roll spelar konsten idag?

Moderna museet inbjuder allmänheten att skicka in artiklar om litteraturens, filmens och bildkonstens roll i dagens moderna samhälle. Ett urval av de inskickade texterna kommer att publiceras på museets webbplats inför en utställning om moderna kulturströmningar. Du bestämmer dig för att delta.

Skriv din artikel. Presentera två (eller tre) litterära verk, filmer och/eller konstbilder. Minst ett exempel ska hämtas från texthäftet. Resonera om på vilket sätt verken speglar det moderna samhället och redogör för vilken roll du anser att litteratur, film och/eller konst har idag.
\end{abstract}

Den andra vanliga skribentrollen som erbjuds kallar jag Den engagerade medborgaren. Denne deltar genom skriften i offentliga samhällsdebatter för att övertyga andra. De empiriska skribenter som ikläder sig denna roll är gemene medborgare som av endera anledningen bestämmer sig för att delta i diskussionen. I och med att de samhällsfrågor som erbjuds har tydliga moraliska aspekter och kopplingar till intimsfären invokeras underkategorier, skribentroller som kan kallas Moralens väktare och Moralliberalen. Ett exempel på en uppgift som erbjuder dessa skribentroller är "Latoxar och arbetsmyror" (s.17). Ett annat exempel kan vara följande: 


\section{B5 På heder och samvete}

Mygel, fusk och lögner är ämnen som många blir berörda av på ett eller annat sätt, vare sig det handlar om att sprida falska rykten om en kompis eller att skaffa sig extra förmåner $i$ jobbet.

Kravet att vara hederlig och ärlig diskuteras på din lokaltidnings webbplats och du bestämmer dig för att skicka in en personlig artikel.

Skriv din artikel. Förklara vad $d u$ anser om hederlighet och jämför det med tendenser som du tycker dig se i yrkeslivet och/eller $i$ övriga samhället. Ge exempel som visar hur ärlighet och hederlighet behandlas i dag.

Och för den delen också följande:

\section{B5 Slagsmål - ett sätt att umgås}

Att småpojkar slåss anser många vara normalt. I högre åldrar är slagsmål på skolgården eller i hockeyrinken inte ovanliga. Även vuxna män kan se våld och slagsmål som något uppiggande och normalt $i$ umgänget med andra män.

Brottsförebyggande rådet, Brå, vill ha allmänhetens syn på män och våld och efterfrågar texter som ska publiceras i en bok. Du bestämmer dig för att bidra.

Skriv ditt inlägg. Redovisa exempel från texthäftet på hur vanliga män umgås genom att slåss. Jämför med egna erfarenheter från sådant du läst, sett eller varit med om. Diskutera vilka konsekvenserna blir för ett samhäller där många män ser slagsmål som ett sätt att umgås.

Utöver dessa två roller förekommer även några erbjudanden om Den engagerade kulturkonsumenten. Denne skriver frivilligt för att upplysa och övertyga medmänniskor om exempelvis bra film, böcker eller resformer, och kan exemplifieras med följande uppgift:

\section{$11 B 3$ En action värd att se}

Actionfilmer har funnits lika länge som film har producerats och genren har alltid haft en trogen publik. Att följa en spännande handling utan att själv behöva utsätta sig för fara tycks locka många tittare.

Tidningen Filmnytt planerar ett temanummer om actionfilmer. De söker nu efter läsarnas egna recensioner. Du bestämmer dig för att skriva om en actionfilm värd att se.

Skriv din recension. Analysera den film du valt med tanke på exempelvis miljöskildring, tekniska effekter, rollfigurer och 
handling. Diskutera vad som gör den till en actionfilm. Motivera varför filmen är sevärd.

Vi har också Eleven som skriver arbete i skolan där hon utforskar ämnen knutna till naturkunskapens, svenskämnets och samhällsämnets kunskapsinnehåll och med Den bedömande läraren som modelläsare. Följande uppgift är ett exempel på det:

\section{B3 Arv och miljö}

Den genetiska forskningen har kommit långt i upptäckten av hur vår arvsmassa fungerar, men hela vår personlighet kan inte förklaras på biokemiskt sätt. Ibland, som till exempel i Lars Ardelius novell Kickan, kan det vara svårt att se vad som har störst betydelse - arv eller miljö. Det finns också andra faktorer som formar människor.

Frågan om vad som präglar människors utveckling ska diskuteras i din skola i ett samarbete mellan svenskämnet och naturkunskapen och arbetet ska redovisas i essäform. En essä är en utredande text där ett aktuellt eller vetenskapligt ämne behandlas på ett personligt sätt.

Skriv din essä. Ge exempel på faktorer som påverkar vår personlighet. Diskutera med hjälp av texthäftet betydelsen av arv och miljö och redovisa din egen inställning.

Slutligen finns förutom fyra uppgifter som öppnar för ett val mellan den självutnämnda folkbildaren och den engagerade medborgaren, också två uppgifter som inte faller inom någon nämnd kategori. En uppgift invokerar Reportern (uppgift 10B8 s. 19) och en Den reflekterande fotbollssupportern som förklarar varför han älskar sin klubb och hur han visar det (jfr s. 18-19).

\section{Potentiella normkonflikter}

Så långt har analysen visat hur uppgifter på olika vis reglerar elevens yttrande. Uppgifterna ger ett perspektiv på ett ämne, ställer skribenten inför en situation som kräver handling, och reglerar grundläggande steg $\mathrm{i}$ hur eleven ska utföra sin handling i situationen. Som nämnt är ett grundläggande antagande som provkonstruktionen bygger på att symmetri råder mellan beskrivningen av situationen och instruktionens normering av hur handlingen ska medieras. Denna antagna normsymmetri blir en realitet när en uppgift konstruerar en och samma modelläsare genom både situationsled och instruktionsled. I flertalet av uppgifterna i det undersökta materialet, och i många av de uppgifter som citerats i den här artikeln, råder denna eftersträvade normsymmetri. Exempelvis konstruerar uppgiften "09B3 Arv och miljö" på föregående sida en och samma skribentroll i både situation och instruktion. Situationen är att eleven befinner sig i skolan och ska redovisa ett fördjupningsarbete om arv och miljö i form av en essä. Vi har en ut- 
forskande grundhandling och instruktionsledet normerar en utredande inre struktur. Ett annat exempel är uppgiften "10B8 Något att bita $i$ " (se s. 12). Situationen är att en kulturtidskrift vill att läsarna skickar in artiklar om vad det är i vampyr- och varulvsskildringar som fascinerar moderna människor, och instruktionen normerar en text om just detta.

Samtidigt finns också uppgifter där normsymmetri mellan situation och instruktion inte är lika självklar. I Skolverkets resultatredovisning (2013:77) analyseras elevlösningar av uppgiften "12B7 Att våga ta steget", nedan. I rapporten bedömer man att innehållet i elevlösningarna tenderat att bli alltför personligt, rentav privat. Eleverna klarar enligt bedömargruppen inte av att "anpassa innehåll och ton efter de givna förutsättningarna - en lokaltidnings läsekrets" (Skolverket 2013:77). Låt oss se hur uppgiften konstruerar skribentrollen:

\section{B7 Att våga ta steget}

Alla människor har en bakgrund som påverkar dem på olika sätt. Många har också valt att bryta gamla mönster och förändra sin situation även om omgivningen inte alltid accepterat det.

Din lokaltidning planerar en serie med temat personlig utveckling och förändring och uppmanar därför läsarna att bidra med krönikor som behandlar ämnet. Du bestämmer sig för att medverka. En krönika är en personligt utformad text om ett aktuellt eller allmänt ämne som kan intressera många.

Skriv din krönika. Diskutera vad som kan begränsa en människas möjligheter att styra över sitt liv eller utvecklas till den hon vill vara. Utveckla din diskussion med hjälp av erfarenheter som finns beskrivna i texthäftet. Ge exempel på egenskaper och/eller förutsättningar som behövs för att våga gå sin egen väg även om det kan bryta mot omgivningens förväntningar.

Skribentrollen i denna uppgift har jag kategoriserat som Den självutnämnda folkbildaren. Rollen uppstår genom det sätt på vilket instruktionsledet uttolkar situationen. Situationen är att lokaltidningen efterfrågar krönikor från gemene läsare om ämnet personlig utveckling. Skribentrollen som ligger i en sådan situation skulle med mediespråk kunna kallas Den vanliga människan. Den vanliga människan skulle här vara den vardagliga röst som belyser ämnet genom att berätta sin egen historia, om sin egen personliga utveckling. I vår provuppgift ger dock instruktionen vid handen att skribenten inte ska berätta sin historia. Istället ska skribenten föra en generisk diskussion om vilka faktorer som påverkar en människas möjlighet att gå sin egen väg i sin personliga utveckling. Uppgiften kräver med andra ord att den empiriske skribenten, den gemene lokaltidningsläsaren, självmant ikläder sig expertrollen som den som förklarar för andra gemene lokaltidningsläsare hur det egentligen ligger till med möjligheter till personlig utveckling allmänt sett. 
Den elev som läser ämnes- och situationsleden och drar på sina erfarenheter av liknande situationer riskerar med andra ord att misslyckas.

En liknande normkonflikt kan ses i följande uppgift:

\section{B7 Jag var där!}

Live-föreställningar som till exempel konserter, ståuppframträd-

3anden, musikaler och gatuteater drar stor publik trots att det mesta går att uppleva via tv och film eller på Internet. Det finns många som under en festival kan stå $\mathrm{i}$ ösregn med lera upp till knäna och ändå tycka att upplevelsen är fantastisk.

Tidskriften Art planerar ett temanummer om live-framträdanden inom olika konstformer och ber läsarna skriva om sina upplevelser. Du bestämmer dig för att bidra med ett inlägg.

Skriv ditt inlägg. Beskriv kortfattat en live-föreställning du varit på. Diskutera med hjälp av texthäftet vad som skiljer en sådan upplevelse från ett inspelat framträdande. Redogör för hur du själv föredrar att uppleva konserter eller andra typer av föreställningar.

Situationen består av att tidskriften Art ber läsarna skriva om sina live-upplevelser. Den elev som drar på sina förkunskaper om sådana situationer skulle mycket väl kunna tänkas ägna hela sin text åt att i egenskap av Den vanliga människan berätta om en fantastisk live-upplevelse. En sådan text skulle i sitt sammanhang mycket väl kunna vara en utmärkt mediering av handlingen att övertyga läsaren om förträffligheten i liveframträdanden. Denna tolkning av situationen skulle dock inte kunna ges textvärde på den aktuella provuppgiften. Instruktionen normerar nämligen en annan form än den personliga erfarenhetens berättelse för att mediera denna handling, nämligen den utredande strukturen. Instruktionen ger vid handen att eleven kortfattat ska ta avstamp i en upplevelse för att sedan utreda frågan vad som på ett generiskt plan skiljer liveframträdanden från inspelade framträdanden. Som exempellösning på betygsnivån IG finns en text där eleven just berättar om ett regnigt och kallt besök på festivalen Sonisphere. Visserligen upplevde textjaget ögonblick av eufori under en konsert, men beskriver i avslutningen hur hen "mådde som bäst när jag kom hem till min varma säng och fick lyssna på musik ur högtalarna i datorn istället". Betyget IG motiveras med att "ställningstagandet är otydligt och tyngs av alltför många privata och ovidkommande detaljer" (Bedömningsanvisningar 2011:49).

Normkonflikten är även intressant ur de två perspektiv på begreppet genre som haft särskilt genomslag i såväl den nordiska didaktiska skrivforskningen (Hertzberg 2001) och den svenskämnesdidaktiska praktiken (exempelvis Holmberg \& Wirdenäs 2010), nämligen det nyretoriska och det genreskolska. Den nyretoriska skolans genrebegrepp är pragmatiskt och klassikern är Miller (1984). Med Millers syn är genrer typifierade handlingar som uppstår ur 
återkommande retoriska situationer. Mer specifikt springer genrerna ur upprepade exigence, påträngande problem som måste hanteras genom handling. Exigence definieras som " $a$ set of particular social patterns and expectations that provides a socially objectified motive for addressing danger, ignorance, separateness" (1984:158). Det påträngande problemet är alltså socialt distribuerat, och genrer blir med denna syn de konventionaliserade textuella och språkliga mönster som gör skribentens sociala (men inte privata) motiv möjliga att känna igen och tolka. Med textteoretisk terminologi kodar genre kulturellt elaborerad intentionalitet. Ställd inför en retorisk situation definierar den skickliga skribenten situationen på ett eller annat sätt som är kulturellt accepterat. Genrerna socialiseras man in i genom att delta i de sociala praktiker som äger dem.

I den australiska genreskolan är utgångspunkten istället lingvistisk. Genre definieras visser-ligen som "staged, goal oriented social processes" (Martin \& Rose 2008:6), men teorin etablerar likväl på lingvistisk och textuell grund en a-priori typologi som består av ett fåtal grundläggande framställningsformer, som beskrivning, berättelse, förklaring, ställningstagande och instruktion (Rothery 1996, Schleppegrell 2004). Genrerna förstås som kulturellt betingade, och de består av inre stegvisa strukturer med obligatoriska och valbara steg. I denna genreförståelse betonas med andra ord textuell form i striktare mening. Draget till sin spets är det den textuella formen allena som bestämmer genren och därmed också den sociala situationen (jfr Holmberg 2012).

Att provkonstruktionen har drag av både nyretorik och genreskola, återspeglas just $\mathrm{i}$ de två huvudsakliga läsarter som bedömningsanvisningarna normerar. En nyretorisk, som bygger på att eleven ska känna igen den situationstyp och genrebeteckningar (artikel, essä etc) som beskrivs i uppgiften, dra på sina erfarenheter av hur det är lämpligt att agera i liknande situationer och skriva utifrån det. Och så en genrepedagogisk där instruktionen sätter en struktur där ett antal steg görs obligatoriska, utifrån vilka uppgifterna utan större tveksamhet kan klassificeras som utredande eller argumenterande. Detta motsvaras av genreskolans förklaring och ställningstagande. När de nyretoriska och genreskolska premisserna för skrivande går isär som i uppgifterna ovan, tycks det givet bedömningsanvisningarna vara den genreskolska medieringen som gäller - de tre uppmaningarna $\mathrm{i}$ instruktionen ska följas. Om relationen mellan genrebeteckningar och instruktioner kan konstateras att det i materialet finns uppgifter som har identiska uppsättningar uppmaningsverb i instruktionerna, men aktualiserar olika genrebeteckningar. Och omvänt finns uppgifter som visserligen har samma genrebeteckning, men där instruktionsleden i ena fallet normerar argumenterande inre struktur, och i andra en utredande. Som vi sett aktualiserar uppgifterna många andra krav än färdighetskunskap kopplat till innebörden i genrebeteckningarna. En undervisning som bygger på beständiga innebörder i genrebeteckningarna i de journalistiska språkdomänerna riskerar att bli kontraproduktiv. 


\section{Sammanfattande diskussion: måldomäner}

Analysen visar hur det ur de enskilda skrivuppgifterna utkristalliseras fyra stycken återkommande skribentroller, eller om man så vill uppgiftstyper. Skribentrollerna hålls samman av någorlunda stabila teman, inre strukturer och grundhandlingar. Dessa har koppling till tre måldomäner med stark historisk tradition i svenskämnet, nämligen kulturell offentlighet, politisk offentlighet och ämnesövergripande skolskrivande. Den kulturella offentligheten är en prioriterad måldomän sett till antalet erbjudanden, med 32 uppgifter, den politiska offentligheten representeras i 17 uppgifter medan det ämnesövergripande skolskrivandet är på undantag med 3 uppgifter.

Den bild proven ger av skrivandet i de olika domänerna är att skrivande i kulturell och politisk offentlighet är drivet av frivillighet, engagemang och folkbildning, medan skolskrivandet är något man gör för att situationen kräver det. Går vi till texthäftena består visserligen den skriftliga kulturella offentlighet provuppgifterna simulerar av texter skrivna av professionella skribenter, författare och journalister. Uppgiftskonstruktionen bygger dock på att den också är öppen för gemene man att genom skriften att utforska frågor om kultur och människa eller övertyga sina medmänniskor i dylika frågor. Den prioriterade inre strukturen i kulturdomänen är den utredande, och de prioriterade skribentrollerna är Folkbildaren och Den engagerade kulturkonsumenten. Den politiska offentligheten är öppen för Den engagerade medborgaren att genom argumenterande text övertyga sina medmänniskor i moralladdade samhällsfrågor. I skolskrivandets måldomän använder Eleven skriften för att utforska frågor med koppling till kunskapsinnehållet i olika skolämnen, med den utredande texten som prioriterad struktur. Som figur 3 visar kan proven sägas vila på en doxa där skrivandet ges mening som ett redskap för humanistisk bildning, för aktivt deltagande i samhällslivet och för skolämneslärande: 


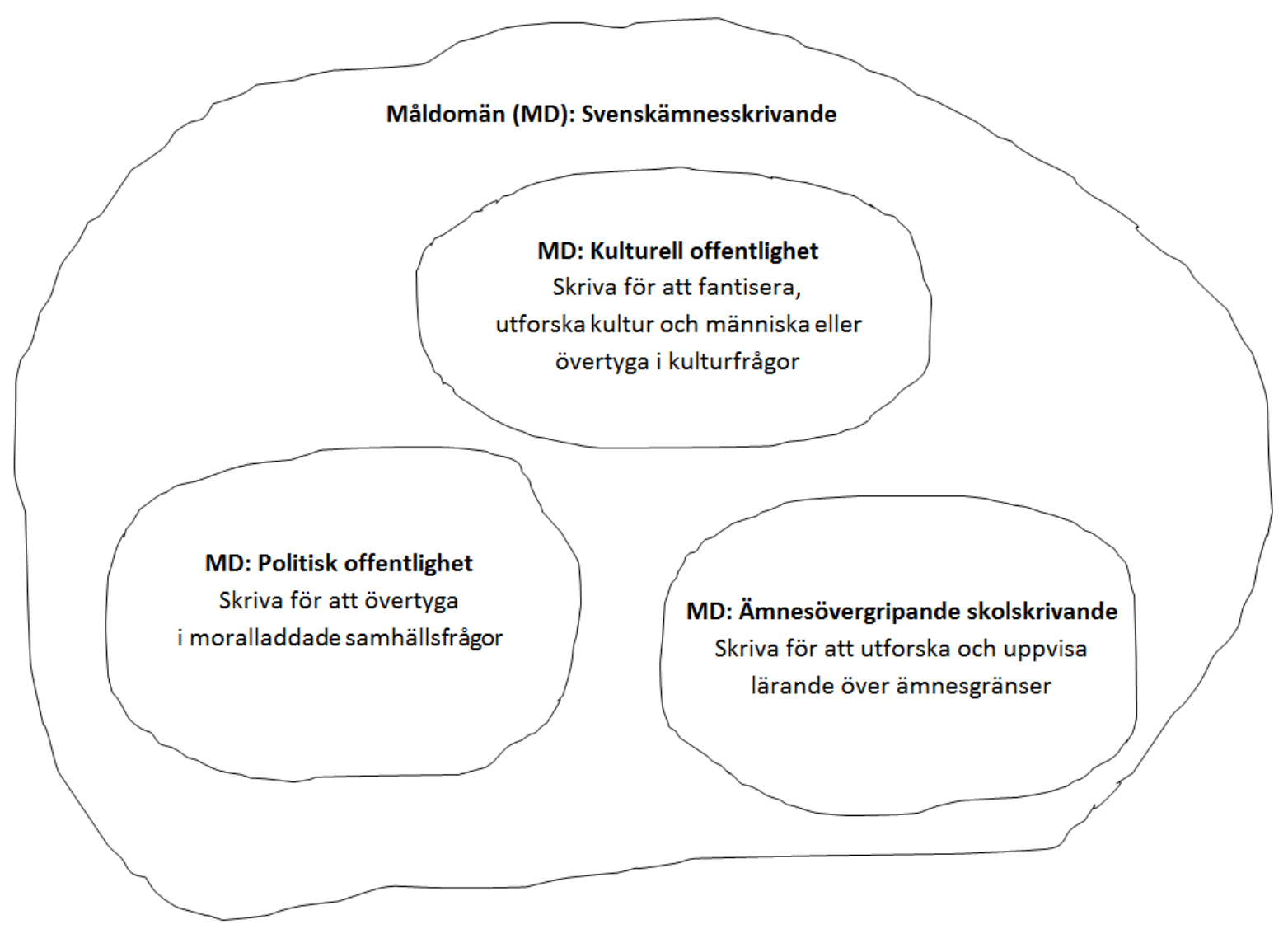

Figur 3, Förslag till förståelse av provens måldomäner.

Den uppdelning av den överordnade svenskämnesdomänen som provkonstruktionen ger uttryck för påminner om Habermas’ teori om det borgerliga samhällets självbeskrivning. Denna har med sin uppdelning mellan privat och offentligt och kultur och politik länge funnits med i resonemang om den svenska skolans, underförstått svenskämnets, uppdrag när det gäller skrivundervisningen (jfr Teleman 1979:30ff). En skillnad mellan proven och modellen är att provens kulturella offentlighet är avgränsad till att utgöras av analyser av, och propåer om, det kulturutbud som i Habermas modell utgör centrum för den kulturella offentligheten. I provkonstruktionen betonas visserligen att elevernas skönlitterärt skrivande, eller berättande text, är viktigt att ta hänsyn till vid betygssättning av eleverna. I tidigare prov fanns skönlitterärt skrivande också med som uppgifter, men dessa togs bort, med dels motivet att de inte har stöd i kursmålet som prövas, dels att skönlitterära texter är alltför svåra att bedöma (Provkonstruktionsgruppen 2011:1). En annan skillnad är att den politiska offentligheten med Habermas har samhällsekonomin i centrum. I provens bild av den politiska offentlighet eleverna ska kunna delta i står istället moralen i centrum. En anledning till detta är rimligtvis att skrivämnena ska vara så allmängiltiga att inte elever med vissa särintressen ( $\mathrm{t}$ ex samhällsekonomi) gynnas framför andra. 
Det kan också vara fruktbart att ställa provkonstruktionens tradition i relation till de fyra olika skrivideologiska positioner, eller intended curriculum, som IEA-undersökningen frilade genom bland annat faktoranalys av styrdokument i olika länder (Saari \& Purves 1992:38ff). En av dessa är den kunskaps- eller kulturarvsorienterade ("knowledge-based or heritage curriculum"), vars mål är att eleverna ska göras medvetna om och kunniga i ett litterärt och retoriskt arv. Det handlar om att erövra och använda kunskaper om dessa arv och/eller erövra en uppsättning traditionella modeller över det bästa sättet att skriva. Svenskämnesprovens tongivande måldomän "Den kulturella offentligheten" kan sägas hämta näring ur denna position, som också Berge (2002:463) visat var starkt framträdande i den norska videregående skolens examenstradition. En annan position i IEA-undersökningen som slår igenom i svenskämnesproven är den värdebaserade ("value-based curriculum"). Här tjänar skrivundervisningen ett större mål med skola och undervisning, nämligen att utveckla och stärka en samhällsgemensam uppsättning värden. Hit kan de moraliskt orienterade argumenterande uppgifterna föras, som uppmuntrar eleverna att aktivt förhålla sig till etiska spörsmål. En tredje position av relevans för svenskämnesproven är den färdighetsinriktade/instrumentalistiska ("competence or skills curriculum"). Målet här är att genom skrivundervisningen erövra en uppsättning delfärdigheter för läsande och skrivande, och att få eleverna till en gemensam nivå av färdighet som bedöms användbar av samhället. Hit kan kanske framförallt uppgifternas betoning på textanvändning och källhänvisning föras. Den fjärde positionen i IEA-undersökningen, är orienterad mot personlig utveckling ("personal growth") och syftar till utvecklandet av varje elevs unika röst och expressiva uttryck. Denna är inte lika framträdande i skrivuppgifterna. Visserligen efterfrågas just elevens egna synpunkter i många uppgifter, men i helhet föreskriver fortfarande uppgifterna skribentroller med tydlig auktoritativ röst, som eleverna har att förhålla sig till.

Proven kan också relateras till Skrivehjulet. Sett till detta samplar svenskproven ett av tre skäl snävt och problematiskt skrivkonstrukt. Det första bekymret är att svenskproven i stort sett uteslutande opererar med två grundläggande skrivhandlingar. Det andra är att innehållet i uppgifterna endast $\mathrm{i}$ ett fătal uppgifter aktualiserar ett ämnesinnehåll med koppling till andra skolämnen än svenskämnet (och i viss utsträckning samhällskunskapsämnet). Och det tredje, och kanske mest centrala bekymret, är att uppgifterna och bedömningsanvisningarna så hårt normerar en på förhand given medieringsform, snarare än att ta utgångspunkt $i$ en skrivhandling för att vid bedömning möta eleven i denna. Om den svenska provkonstruktionen utvecklats med bas i Skrivehjulet hade analysen därför väckt hypotesen att validiteten i de svenska proven undergrävs av både under-representering av centrala aspekter av konstruktet och konstrukt-irrelevant varians (jfr Messick 1989:34).

Men nu är det konstrukt som svenskproven utvecklats ifrån inte Skrivehjulet, utan de demokratiskt fastlagda kursmålen. Givet uttolkningen av dessa mål att texter är antingen argumenterande eller utredande får provkonstruktionen sägas ha goda förutsättningar att sampla målet. Uttolkningen kan också sägas få teoretiskt stöd i genreskolan, som i sina typologier 
vanligtvis beskriver dessa analytiska genrer som de mest komplexa, och framhåller dem som just slutmålet i den önskvärda progressionen i skrivundervisningen (jfr Schleppegrell 2004:82ff). Utmaningen sett ur detta perspektiv är snarare i vilken utsträckning ämneskunskaper utöver litteraturkunskap ingår i konstruktet. Provet rör sig som visats inom relativt homogena tematiska områden.

Ett viktigt resultat av analysen är emellertid att provens två huvudsakliga anspråk stundom hamnar i konflikt. Sett ur perspektivet att bedömningspremisserna bör vara så tydliga som möjligt för elever och lärare, torde det vara lämpligt att välja spår. Provkonstruktionen har så att välja mellan att antingen göra anspråk på att mäta utredande och argumenterande text som genrer i egen rätt, alternativt att mäta elevers förmåga att hantera retoriska situationer genom skriftlig mediering av handling. Går man på den förra linjen bör provkonstruktionen vara öppnare med att det är just dessa två genrer man opererar med, och vilka formkrav dessa kommer med. I uppgifternas instruktionsled kan de journalistiska genrebeteckningarna lämpligen ersättas av uppmaningar i stil med "Skriv en utredande text", följt av obligatoriska steg i strukturen. Ett vanligt argument för en textstrukturellt orienterad pedagogik är att den är lämplig för att stötta de svagaste skribenterna (jfr Smedegard 2013 för en sådan argumentation angående den danska grundskolans examenstradition). Ett argument emot är den risk för formalism $\mathrm{i}$ skrivundervisningen som följer.

Den andra linjen, att välja att pröva elevernas förmåga att hantera retoriska situationer, torde följas av större förändringar i provkonstruktionen. Detta som uppgifterna i så fall bör överlämna åt eleven att själv ansvara för att etablera intentionaliteten i sin text (jfr Berge 2005 om den norska grundskolans examensprov). Sett ur detta perspektiv framstår de idag så framträdande instruktionsleden som problematiska. Vill vi mäta elevers förmåga att mediera handlingar i retoriska situationer är textstruktur inte en ovidkommande aspekt vid bedömning. Men aspekten är en a posteriori-kategori snarare än en på förhand given. Det vill säga frågan blir inte i vilken utsträckning elevtexten uppvisar "rätt" textstruktur, utan hur eleven använder textstruktur som en av flera resurser för att realisera intentionalitet i sin text.

\section{Referenslista}

af Geijerstam, Å. (2004): Att skriva i naturorienterade ämnen i skolan. Institutionen för lingvistik och filologi, Uppsala universitet. Uppsala: Uppsala universitet

Bachman, L., \& Palmer, A. (2010): Language assessment in practice. Oxford: Oxford university press

Berge, K.L. (1996): Norsksensorenes tekstnormer og doxa: en kultursemiotisk och tekstsociologisk analyse. Doktorsavhandling, Institutt for anvendt språkvitenskap, Norges teknisk-naturvitenskaplige universitet. Trondheim: Norges teknisk-naturvitenskaplige universitet

Berge, K.L. (2001): "From utterance to text, again: theoretical reflections on the notion of "text" based on empirical studies of writing in different context". I: P. Coppock (Red.) The Semiotics of writing: transdisciplinary perspectives on the technology of writing. (s. 157-182). Bologna: Brepols. 
Berge, K.L. (2002): “Hidden norms in Assessment of Students' Exam essays in Norwegian Upper Secondary School". I: Written communication, 19, s. 458-492.

Berge (2005): “Tekstkulturer og tekstkvaliteter”. I: Berge, K.L., Evensen, L.S., Hertzberg, F. \& Vagle, W. (Red.) (2005b) Ungdommers skrivekompetanse Bind II: Norskeksamen som tekst, (s. 11-190). Oslo: Universitetsforlaget.

Berge, K.L. (2008): “Teksten”. I: K. Asdal m.fl (Red.) Tekst og historie. A lese tekster historisk. (s. 33-68). Oslo: Universitetsforlaget.

Berge, K.L. (2013): “Om forskjellene mellom systemisk-funktionell lingvistikk og tekstvitenskap”. I: S. Matre, D. Kibsgaard Sjøhelle, \& R. Solheim (Red.) Teorier i møte med skolens lese- og skrivepraksiser (1. utg., s. 72-90). Oslo: Universitetsforlaget.

Berge, K.L., Evensen, L.S., Hertzberg, F. \& Vagle, W. (Red.) (2005a): Ungdommers skrivekompetanse Bind I: Norsksensuren som kvalitetsvurdering. Oslo: Universitetsforlaget.

Berge, K.L., Evensen, L.S., Hertzberg, F. \& Vagle, W. (Red.) (2005b): Ungdommers skrivekompetanse Bind II: Norskeksamen som tekst. Oslo: Universitetsforlaget.

Blåsjö, M. (2004): Studenters skrivande i två kunskapsbyggande miljöer. Doktorsavhandling, Institutionen för nordiska språk, Stockholms universitet. Stockholm: Almqvist \& Wiksell.

Borgström, E. (2010): “Att skriva prov. Om normer och textstrukturer i gymnasieskolans skriftliga nationella prov”. I: Språk \& Stil, 20, 132-164.

Borgström, E. (2012): “Skrivförmåga på prov”. I: G. Skar \& M. Tengberg (Red.) Svensklärarföreningens årsskrift 2012. Svensklärarserien, 235, s. 209-223.

Chatman, S. (1990): Coming to terms. The rhetoric of narrative in fiction and film. Ithaca, New York: Cornell university press.

DeSeCo (2005): “The definition and selection of key competencies, executive summary”. Hämtat 15:e september 2013, från: http://www.oecd.org/pisa/35070367.pdf

Eco, U. (1994): Six walks in the fictional woods. Cambridge, Mass.: Harvard university press.

Evensen, L.S. (2010): “En gyldig vurdering av elevers skrivekompetanse?”. I: J. Smidt (Red.) Rammer for skriving: om skriveutvikling i skole og yrkesliv (1. utg., s. 13-31). Trondheim: Tapir forlag.

Gustafsson, J.E. \& Erickson, G. (2013): "To trust or not to trust? Teacher marking versus external marking of national tests". Educational Assessment, Evaluation and Accountability, 25:1, s 69-87.

Holmberg, P., \& Wirdenäs, K. (2010): "Skrivpedagogik i praktiken. Textkedjor, textsamtal och texttypologier i tre svensklärares klassrum". Språk \& Stil, 20, s. 105-131.

Holmberg, P. (2012): "Skolskrivande, genre och register. En jämförelse mellan två systemisk-funktionella kontextmodeller”. I: T. Hestbæk Andersen \& M. Boeriis (Red.) Nordisk socialsemiotik: pcedagogiske, multimodale og sprogvidenskabelige landvindinger (s. 221-245). Odense: Syddansk universitetsforlag.

Hultman, T.G. (1989): “Skrivutveckling i ett pedagogiskt perspektiv”. I: C. Sandqvist \& U. Teleman (Red.) Språkutveckling under skoltiden. Lund: Studentlitteratur.

Hultman, T.G. \& Westman, M. (1977): Gymnasistsvenska. Lund: Liber läromedel.

Kane, M. (2006): "Validation". I: R.L. Brennan (Red.) Educational measurement, 6, s. 17-64

Kane, M., Crooks, T. \& Cohen, A. (1999): "Validating measures of performance". Educational measurement: issues and practice, 18:2, s. 5-17.

Krogh, E., \& Hobel, P. (2013): “ “Årets bedste opgave”: en analyse af en elevtekst i dens kontekst”. I: S. Matre, D. Kibsgaard Sjøhelle, \& R. Solheim (Red.) Teorier i møte med skolens lese- og skrivepraksiser (1. utg., s. 72-90). Oslo: Universitetsforlaget.

Larsson, K. (1984): Skrivförmåga: studier i svenskt elevspråk. Malmö: Liber förlag.

Ledin, P. (2000): Veckopressens historia del II. Rapport nr 29 från projektet Svensk sakprosa. Lunds universitet: Institutionen för nordiska språk.

Ledin, P. (2013): "Den kulturella texten: format och genre". Viden om laesning, nr. 13, s. 6-18.

Lundahl, C. (2010): Varför nationella prov? Framväxt, dilemman, möjligheter. Lund: Studentlitteratur.

Martin, J.R. \& Rose, D. (2008) : Genre relations. Mapping culture. London: Equinox.

Messick, S.A. (1989) "Validity". I: R.L. Linn (Red.) Educational measurement (3:e utg. s. 13-103). New York: American Council on Education/Macmillan.

Miller, C. (1984): “Genre as social action”. Quarterly journal of speech, 70, s. 151-167.

Normprosjektet (2012): Skrivehandlinger og skriveoppgaver. Prosjektmateriale. 
Nygårds Larsson, P. (2011): Biologiämnets texter. Text, språk och lärande i en språkligt heterogen gymnasieklass . Doktorsavhandling, Humanistiska fakulteten, Lunds universitet. Malmö: Malmö studies in educational sciences.

Nyström, C. (2000): Gymnasisters skrivande. En studie av genre, textstruktur och sammanhang. Doktorsavhandling, Institutionen för nordiska språk, Uppsala universitet. Uppsala: Uppsala universitet.

Ongstad, S. (1997): Sjanger, posisjonering og oppgaveideologier: et teoretisk-empirisk bidrag til et tverrfaglig, semiotisk og didaktisk sjangerbergrep. Doktorsavhandling, Institutt for anvendt språkvitenskap, Norges teknisk-naturvetenskaplige universitet. Trondheim: Norges teknisk-naturvetenskaplige universitet.

Parmenius-Swärd (u.u.): "Elevers möte med skrivuppgifter i nationella prov".

Provkonstruktionsgruppen (2007): Sammanställning av uppgifter från lärarenkät vid kursprovet Moderna tider, vt 2007. Hämtad 16:e September 2013, från http://www.natprov.nordiska.uu.se/forskningochpublikationer/publikationer/

Provkonstruktionsgruppen (2008): Sammanställning av uppgifter från lärarenkät vid kursprovet Saga och sanning, vt 2008. Hämtad 16:e September 2013, från http://www.natprov.nordiska.uu.se/forskningochpublikationer/publikationer/

Provkonstruktionsgruppen (2009): Sammanställning av uppgifter från lärarenkät vid kursprovet Engagemang och påverkan, vt 2009. Hämtad 16:e September 2013, från http://www.natprov.nordiska.uu.se/forskningochpublikationer/publikationer/

Provkonstruktionsgruppen (2010): Sammanställning av uppgifter från lärarenkät vid kursprovet Oss emellan, vt 2010. Hämtad 16:e September 2013, från http://www.natprov.nordiska.uu.se/forskningochpublikationer/publikationer/

Provkonstruktionsgruppen (2011): Sammanställning av uppgifter från lärarenkät vid kursprovet Tecken och signaler, vt 2011. Hämtad 16:e September 2013, från http://www.natprov.nordiska.uu.se/forskningochpublikationer/publikationer/

Provkonstruktionsgruppen (2012): Sammanställning av uppgifter från lärarenkät vid kursprovet Dit vinden blåser om trend, utveckling och förändring, vt 2012. Hämtad 16:e September 2013, från http://www.natprov.nordiska.uu.se/forskningochpublikationer/publikationer/

Purves, A.C., Gorman, T.P. \& Takala, S. (1988): “The development of the scoring scheme and scales". I: T.P. Gorman, A.C. Purves \& R.E. Degenhart (Red.) The IEA Study of Written Composition I: The international Writing Tasks and Scoring Scales (s.41-58). Oxford: Pergamon press.

Rothary, Joan (1996): "Making changes. Developing an educational linguistics”. I: R. Hasan \& G. Williams (Red.) Literacy in society (s. 86-123). London: Longman.

Saari H., \& Purves, A.C. (1992): "The curriculum in mother-tongue and written composition". I: A.C. Purves (Red.) The IEA Study of Written Composition II: Education and Performance in Fourteen Countries (s. 37-86). Oxford: Pergamon press.

Schleppegrell, M. J. (2006): The language of schooling. A functional linguistics perspective. New Jersey: Lawrence Erlbaum associates.

Siris, kvalitet och resultat i skolan (odaterad): hämtad 16:e September 2013, från http://siris.skolverket.se/

Skjelten, S.M. (2013): Jakta på kvalitetsforskjellar i elevane sine tekstar. Kva skil gode tekstar frå middels gode? Doktorsavhandling, Det utdanningsvitenskapelige fakultet, Universitet i Oslo. Oslo: Universitetet i Oslo.

Skolverket (1994): Läroplan för de frivilliga skolformerna. Stockholm: Utbildnings-departementet.

Skolverket (2011): Gymnasieskolans kursprov vt 2010. En resultatredovisning. Hämtad 16:e September 2013, från http://www.skolverket.se/publikationer?id=2512

Skolverket (2013): Gymnasieskolans kursprov vt 2012. En resultatredovisning. Hämtad 16:e September 2013, från http://www.skolverket.se/publikationer?id=3010

Smedegard, A. (2013): "Hvem sagde hvorfor? - Skolegenrers situationelle og kognitive forankring”. Viden om loesning, nr. 13, s. 68-80.

Swales, J. (1990): Genre analysis. English in academic and research settings. Cambridge: Cambridge university press.

Teleman, U. (1979): Språk \& rätt. Lund: Liber läromedel.

Tirkonen-Condit, S. (1985) Argumentative text structure and translation. Doktorsavhandling, Studia philologica jyväskyläensia, Jyväskylä 
Vähäpassi, A. (1988): “The domain of school writing and development of the writing tasks”. I: T.P. Gorman, A.C. Purves \& R.E. Degenhart (Red.) The IEA Study of Written Composition I: The international Writing Tasks and Scoring Scales (s.15-40). Oxford: Pergamon press.

Wertsch, J.V. (1993): Voices of the mind. A sociocultural approach to mediated action. Cambridge, Mass.: Harvard university press.

Östlund-Stjärnegårdh, E. (2002): Godkänd i svenska? Bedömning och analys av gymnasieelevers texter. Doktorsavhandling, Institutionen för nordiska språk, Uppsala universitet. Uppsala: Uppsala universitet.

\section{Provmaterialet}

Bedömningsanvisningar, Kursprov Svenska/Svenska som andraspråk B, vårterminer 2007-2012. Skolverket. Lärarinformation, Kursprov Svenska/Svenska som andraspråk B, vårterminer 2007-2012. Skolverket.

Texthäfte till det nationella kursprovet i svenska och svenska som andra språk, vårterminer 2007-2012. Skolverket.

Uppgifter till delprov B: skriftligt delprov. Svenska/svenska som andraspråk B, vårterminer 2007-2012. Skolverket. 